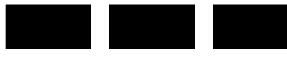 \\ F \\ ThE WiLliam DAVIDSON INSTITUTE \\ AT THE UNIVERSITY OF MICHIGAN
}

\section{Catching-up and inflation in Europe: Balassa- Samuelson, Engel's Law and other Culprits}

\author{
By: Balázs Égert
}

William Davidson Institute Working Paper Number 991

June 2010 


\title{
Catching-up and inflation in Europe: Balassa- Samuelson, Engel's Law and other Culprits
}

\author{
Balázs Égert ${ }^{1}$ \\ OECD
}

\begin{abstract}
This study analyses the impact of economic catching-up on annual inflation rates in the European Union with a special focus on the new member countries of Central and Eastern Europe. Using an array of estimation methods, we show that the Balassa-Samuelson effect is not an important driver of inflation rates. By contrast, we find that the initial price level and regulated prices strongly affect inflation outcomes in a nonlinear manner and that the extension of Engel's Law may hold during periods of very fast growth. We interpret these results as a sign that price level convergence comes from goods, market and non-makret service prices. Furthermore, we find that the Phillips curve flattens with a decline in the inflation rate, that inflation is more persistant and that commodity prices have a stronger effect on inflation in a higher inflation environment.
\end{abstract}

JEL: E43, E50, E52, C22, G21, O52

Keywords: European Union, inflation, Balassa-Samuelson, real convergence, catching up, Bayesian model average, non-linearity.

\footnotetext{
${ }^{1}$ OECD, Economics Department. CESifo; University of Paris X Nanterre and the William Davidson Insittute. The author thanks Boris Cournède, Isabell Koske, Annabelle Mourougane, participants at the ACES/ASSA 2008 meetings in New Orleans and a DG ECFIN/European Commission workshop and two anonymous referees for helpful comments and suggestions. The usual disclaimer applies. Email: balazs.egert@oecd.org
} 


\section{Introduction}

The price level of a less developed countries is usually lower than the price level observed in a more developed economies. This pattern can be observed within the enlarged European Union where new EU member countries have lower prices when compared to old EU countries: the relative price level of GDP ranged from 40 percent (Bulgaria) to 80 percent (Slovenia) of the average of the old EU-15 in 2008 (Figure 1).

Nevertheless, these differences decreased markedly over the last decade. Economic catching-up (real convergence) is thought to drive price level convergence. According to scatterplots drawn in Figure 2, the rate of growth of per capita income (measured in Purchasing Power Standard terms) appears to be positively correlated to inflation rates, whether measured at annual frequency or based on multi-year averages.

It is widely accepted that lower price levels in less developed countries are a result of the lower price level of services. Price levels convergence thus occurs as a result of service price inflation. Yet this view is not fully supported by empirical observations from the European union. Figure 1 shows that in 1999 the price level of consumer goods in new EU member states reached 40 to $60 \%$ of the EU-15 average and that prices of durable goods were by around $20 \%$ below the EU- 15 average in the same year. By 2008, however, the gap for consumer goods decreased to a large extent while the relative price level of durable goods reached the EU-15 average.

Figure 1. GDP price levels and Price level of consumer goods and services (EU-15 average=100), 1999 and 2005/2007

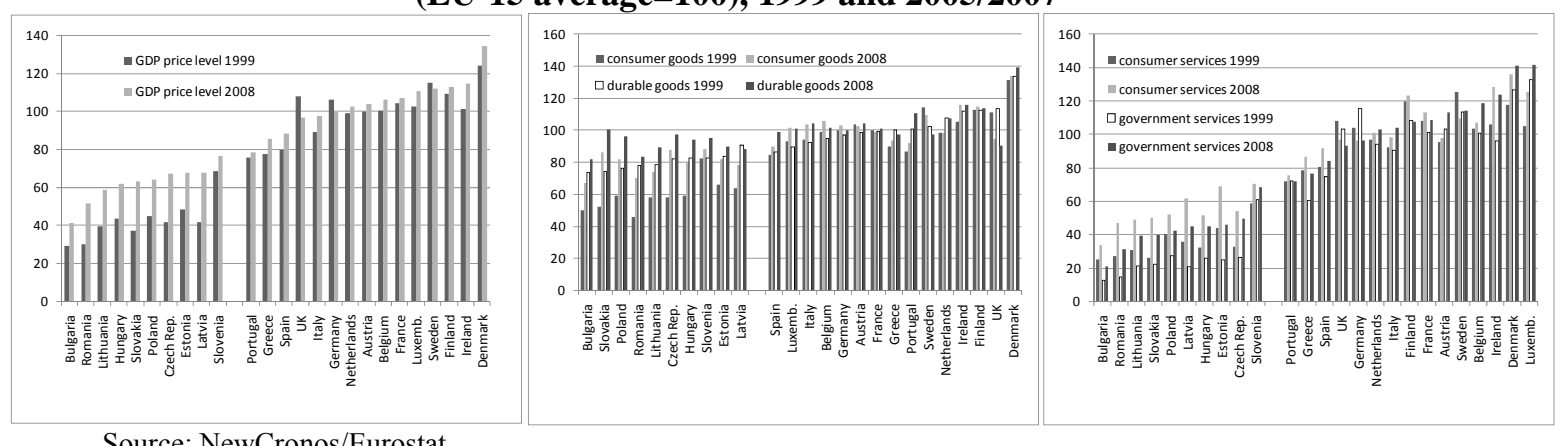

Source: NewCronos/Eurostat 
Figure 2. Real GDP per capita growth and inflation in the EU-27, 1997-2007

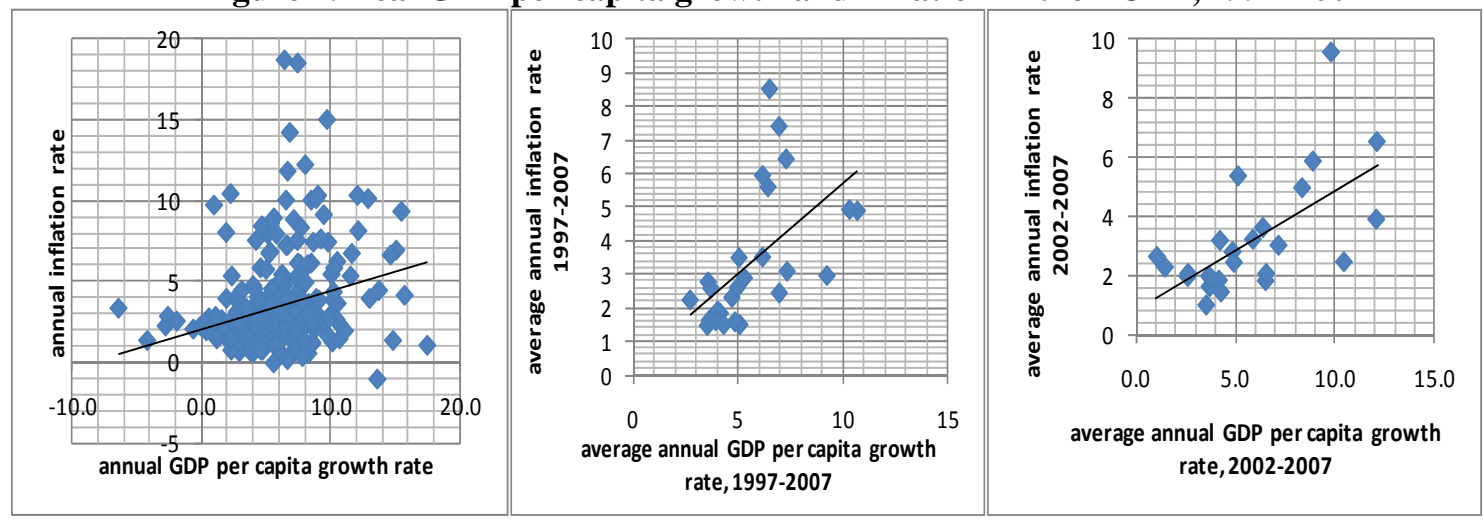

Source: Author's calculations based on data obtained from NewCronos/Eurostat and AMECO/European Commission

Notes: Romania is not included in the figures because of its high triple and double digit inflation rates in the late 1990s.

The driving forces of inflation rates in Europe including old and new EU member states have been in the centre of research interest in academic and policy circles since the start of economic transition and after the introduction of the single currency. ${ }^{2}$ For the euro area, the interest is due to understanding factors that explain inflation differentials within the single currency union. For new EU member states, euro adoption begs a similar question: will lower initial price levels and the ongoing catching-up process lead to higher inflation rates in the longer run by increasing inflation dispersion within the euro area?

This study first discusses the possible causes of higher inflation related to economic catching-up in Central and Eastern Europe and provide some descriptive statistics. Among others, we give an update on the possible size of the Balassa-Samuelson effect in Europe and seek to disentangle the transmission from productivity to inflation. Furthermore, we describe other structural factors affecting goods, services and house prices. Second, we use linear and non-linear econometric estimation methods to analyse the extent to which factors related to economic catching-up influence inflation rates from 1998 to 2007 in the enlarged European Union.

The roadmap of this study is the following. Section 2 describes factors related to economic catching-up that influence inflation rates. Section 3 deals with data and estimation issues. Section 4 presents the estimation results. Section 5 gives the conclusions.

\footnotetext{
${ }^{2}$ See e.g. Backé et al (2003) for early attempt to quantify the effect of different factors in Central and Eastern Europe. More recently, Hammermann (2007), Hammermann and Flanagan (2009), Choueiri et al (2008), Mody and Ohnsorge (2007) and Zoli (2009) analysed inflation developments in Central and Eastern Europe. On the issue, see also Dobrinsky (2006), Lommatzsch and Tober (2004) and MacDonald and Wójcik (2008). Kocenda et al (2006) analysed nominal convergence of inflation rates in CEE countries. Honohan and Lane (2004), Hofmann and Remsperger (2005) and Bulir and Hurnik (2008) studied inflation differentials in the euro area. Rogers $(2001,2002)$ studied the case of the US.
} 


\section{Drivers of inflation rates due to real convergence}

This section overviews factors that are likely to have an impact on inflation rates of fast growing economies. They include factors affecting market-based services, regulated services, goods prices and house prices.

\section{Market-based service prices: The Balassa-Samuleson effect}

The Balassa-Samuelson effect is a compelling starting point for explaning higher inflation rates in fast growing economies. Yet its empirical relevance in new EU member states is not uncontroversial. Studies based on data for the 1990s found the Balassa-Samuelson effect of having a sizeable impact on inflation rates in Central and Eastern Europe, whereas more recent studies came to the conclusion that the impact of the Balassa-Samuelson effect on the inflation rate was between zero and two percentage points annually (Mihaljek and Klau, 2008; and papers cited in Égert et al, 2006). Here we provide an update of these figures using a simple accounting framework, according to which the inflation rate that is attributable to the Balassa-Samuelson effect equals the growth rate of productivity in the tradable sector over that in the nontradable sector multiplied by the share of nontradables in the inflation rate as shown in equation (1):

$$
\Delta \mathrm{p}^{\mathrm{B}-\mathrm{S}}=(1-\alpha)\left(\Delta \operatorname{prod}^{\mathrm{T}}-\Delta \operatorname{prod}^{\mathrm{NT}}\right)
$$

where $\Delta \operatorname{prod}^{\mathrm{T}}$ and $\Delta \operatorname{prod}^{\mathrm{NT}}$ are the rate of growth of average labour productivity in the tradable and nontradable sectors, respectively, and $(1-\alpha)$ is the share of services in the inflation basket.

Using data drawn from the NewCronos database of Eurostat, our results for the new EU member states broadly corroborate results of recent studies. First, the estimated size of the balassaSamuelson effect is below 2 p.p. per annum and is often close to zero. Second, there is some uncertainty regarding the size of the Balassa-Samuelson effect as results are sensitive to alternative sectoral classifications (using manufacturing vs. industry for tradables, and market services vs. total services including all kind of public services) and, in some cases, to the fact whether labour productivity is measured in terms of number of workers, number of full-time equivalent workers or hours worked. Finally, the Balassa-Samuelson effect in the new EU member states are not higher than those found for old EU member states (Figure 3). 
Figure 3. The implied Balassa-Samuelson effect, 1997-2007

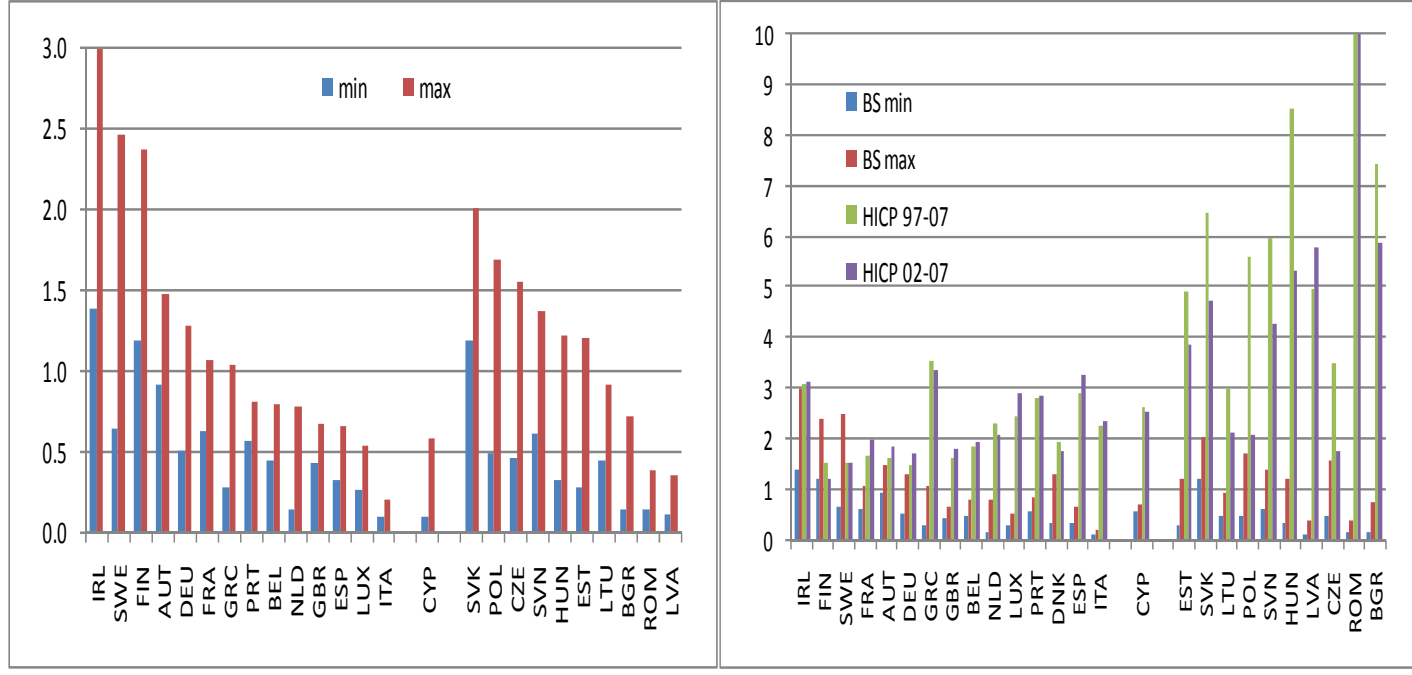

Source: Author's calculations based on data obtained from NewCronos/Eurostat and AMECO/European Commission Notes: Min and Max refer to the lowest and highest figures of the implied Balassa-Samuelson effect reported in Table 1.

At first sight, the size of the Balassa-Samuelson effect in the new EU member countries is puzzlingly low given the large productivity gains these countries recorded in their manufacturing sector (Figure 4). Yet this puzzle can be explained by looking at the accounting framework and the underlying equation (1):

- First, productivity gains in the nontradable sector were substantial, especially in the Baltic states where they reached $5 \%$ per annum, but also in the other CEE countries (Figure 4). The very small Balassa-Samuelson effect in Latvia and Bulgaria is due to the fact that productivity growth in the nontradable sector was very close to that in the tradable sector.

- Second, the share of (market) nontradables in the HICP is low in the CEE economies. The share of market services ranged, in 2007, from about $10 \%$ to $25 \%$ for the CEE economies. By comparison, it varied between 20 percent (Sweden) and 35 percent (Austria) in the old EU countries. The low share of market non-tradables in the HICP mechanically dampens the impact of any productivity growth on overall inflation (Figure 4). 
Figure 4. Average labour productivity growth and the share of total services in the HICP

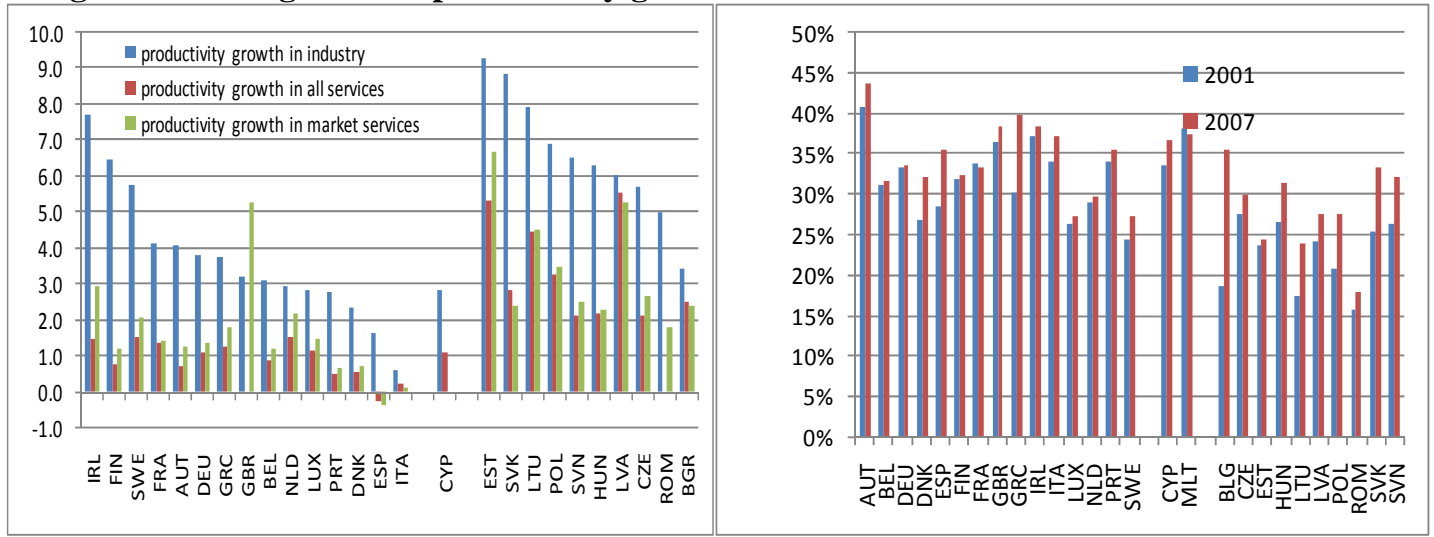

Source: Author's calculations based on data obtained from NewCronos/Eurostat and AMECO/European Commission

Notes: Min and Max refer to the lowest and highest figures of the implied Balassa-Samuelson effect reported in Table A1. The productivity growth in industry is calculated on the basis of hours worked. Exceptions are Belgium, Latvia, Luxembourg, Portugal, Slovenia and UK for which countries only data on (the number of) employment are available.

The two factors described above are responsible for the low estimates of the Balassa-Samuelson effect reported in Figure 3. These results can yet be viewed as upper bound estimates because the simple accounting framework posits a proportionate relationship between the productivity differential and the relative price of market nontradables.

$$
\Delta \mathrm{p}^{\mathrm{B}-\mathrm{S}}=(1-\alpha) \beta\left(\Delta \operatorname{prod}^{\mathrm{T}}-\Delta \operatorname{prod}^{\mathrm{NT}}\right)
$$

Where $\beta$ is supposed to equal 1. This relationship needs not be proportionate for at least two reasons. First, real wage growth in the tradable sector may grow more slowly than productivity in the same sector because very high aggregate productivity growth rates in the tradable sector may mask a large intra-sectoral productivity dispersion. Large intra-sectoral productivity dispersion may cause aggregate productivity growth not to translate into proportionate real wage growth as wage growth in very high productivity growth industries is unlikely to keep up with productivity growth. This in turn could jeopardise the overall wage-setting role of the tradable sector. The dispersion of productivity growth in manufacturing tends to be higher in the new EU member countries with higher overall productivity growth in the manufacturing.

The second factor that could work against productivity growth feeding fully into the relative price of nontradables is incomplete wage equalisation between the tradable and nontradable sector. If wages grow faster in the tradable sector as compared to the nontradable sector, productivity gains would not feed into the relative price of nontradable. 


\section{Regulated services}

Regulated prices are important for inflation developments because they generally account for a considerable chunk of the HICP and because they tend to increase faster than market-based services or other components of the HICP (Figure 5). The reason for these above-average changes is twofold. First, it is the heritage of the transition process during which prices were converging to cost recovery levels. Second, network industries in new EU member states are regulated on a cost plus (or rate of return) basis. Such a regulatory regime does not put pressure on the incumbents to operate more efficiently as they can pass cost increases onto consumers. Therefore, introducing incentive regulation would help foster investment in cost efficient technologoies.

Figure 5. Weight of regulated services (left) and household energy (right) in the HICP

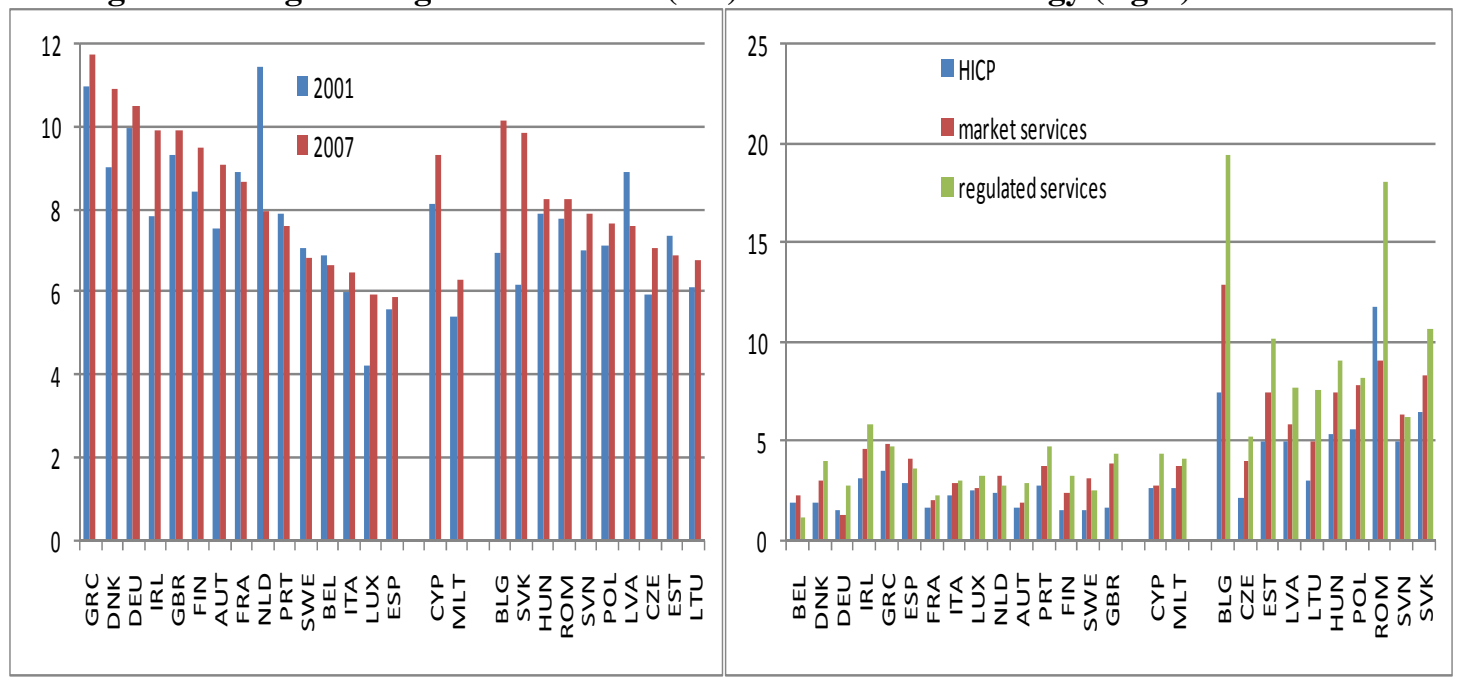

Source: Author's calculations using data drawn from NewCronos/Eurostat

\section{Residential house prices}

Several factors can cause house prices to increase in the longer run in catching up economies.

First, real convergence means that richer households need better quality accommodations. Quality changes may then show up in construction costs or in house prices if quality changes are not adjusted for, which is the case in practice. Second, real convergence means convergence of wages. Higher wages in turn increase construction costs because building activities are labour intensive. Third, the rapid development of underdevelopped credit and mortgage markets in the new member states over the last 15 years or so increased affordability and thus demand for housing and thus resulted in house price increases. 
House prices, not included in the HICP, can influence overall inflation through through several channel: directly via the rent component and indirectly via the impact of possible wealth effects on consumption. Over the last ten years or so, house prices grew at a rapid pace in Central and Eastern Europe, and house price developments are in sharp contrast with the evolution of the overall inflation index in all CEE economies except the Czech Republic and Hungary (Figure 6). At the same time, rents also increased faster than average inflation. Figure 6 reveals a possibly positive relationship between house prices and rents. The share of rents in the HICP is considerably higher in Western Europe, mainly because home ownership ratios are much lower.

Figure 6. House prices

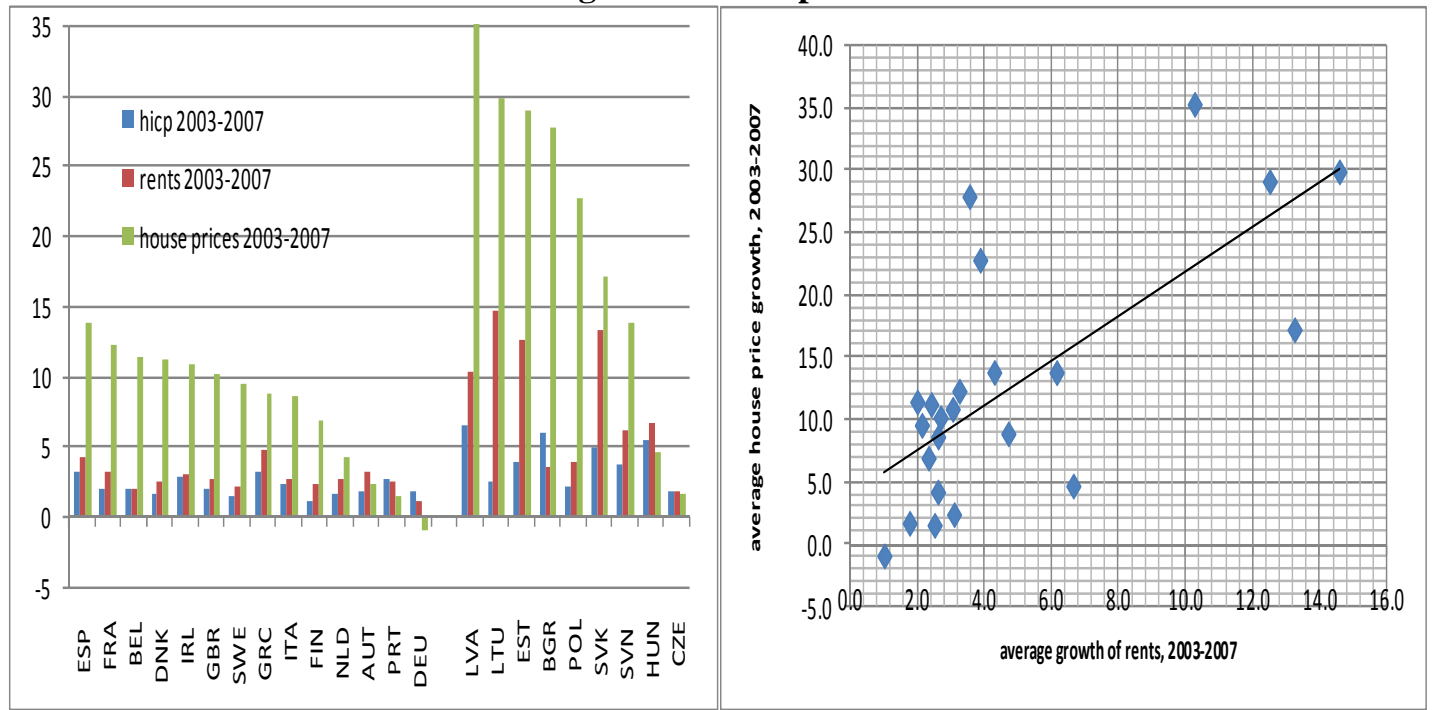

Source: Author's calculations. Rents and hicp are drawn from NewCronos/Eurostat. House prices are obtained from the following sources. OECD Economic Outlook database: Germany, France, Italy, UK, Denmark, Spain, Ireland, Netherlands, Sweden; BIS Macroeconomic database: Portugal, Greece, Austria, Belgium, Bulgaria, Czech Republic, National sources: Hungary (Statistical Office + central bank), Slovenia (central bank), Slovakia (central bank), Estonia (statistical office), Ober-Haus: Latvia, Lithuania, Poland.

Notes: House prices for Estonia are obtained as the average of house prices of the three largest Estonian cities. House prices for Poland are obtained as the average of house prices in Warsaw and Krakowy. House prices for Latvia, Lithuania and Slovenia are house prices of the capital cities.

\section{Goods prices}

Price level convergence and higher inflation rates can be expected to come from goods prices if the price level of goods of new EU member countries is also below the average of the old member countries . Figure 7 shows that long-term (10-year average) inflation of non-energy goods tend to have a positive relationship to the growth rate of real per capita income (in PPS). 
Figure 7. Economic growth and goods prices, 1997-2007

Source: author's calculations based on data drawn from NewCronos/Eurostat and AMECO/European Commission

Notes: The data used for calculating average growth rates start in 2001 for the Czech Republic and Slovenia and in 2002 for hungary and Romania due to the lack of price data

A number of reasons exist why goods prices may increase during economic catching-up:

\section{Quality improvement in goods left unadjusted in price statistics}

Poorer households buy cheaper goods that are of lower quality. Wealthier households pay more attention to the quality of the goods they purchase and are prepared to pay a correspondingly higher price. This can be thought of as an extension of Engel's Law according to which richer households spend less of their budget on food than poorer households do (Figure 8): not only there is a shift away from food in private household spending as households grow richer but households also upgrade the quality of the goods (including foodstuff) included in their consumption basket. In other words, wealthier consumers are more quality sensitive, while poorer households are more sensitive to prices.

A shift towards higher goods prices can occur through a simple shift towards better quality goods. However, a special case of this shift may occur in fast catching-up transition economies, where this shift towards more quality goods on the consumer side is matched with a shift towards more quality goods on the producer side.

Obviously, quality effects should not show up in inflation rates. In practice, however, filtering out quality effects is difficult even for developed countries, let alone the cases where those changes happen more rapidly. According to Ahnert and Kenny (2004), most CEE countries do not use systematically hedonic quality adjustments) to eliminate quality effects from price statistics. 
Figure 8. Economic development and consumption patterns, 1997-2007
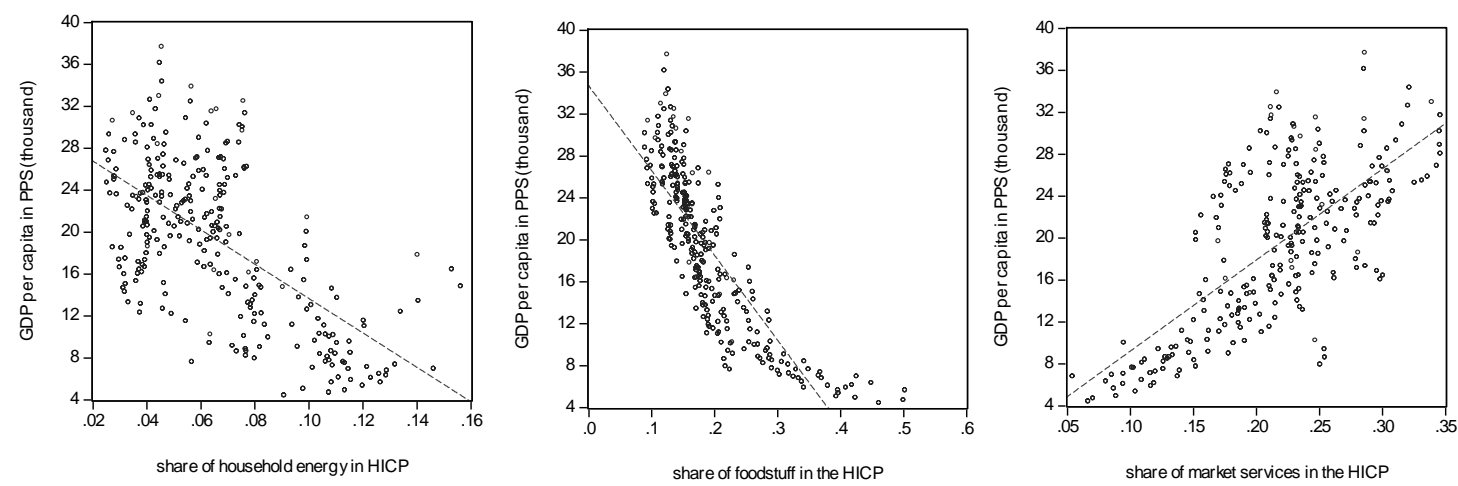

Source: author's calculations based on data drawn from NewCronos/Eurostat and AMECO/European Commission

\section{Pricing-to-market practices}

The prices of identical goods may differ across countries because producers may price their products in line with disposable income. Convergence in disposable income levels would eliminate these differences by generating higher inflation rates in the catching-up economies. This might be especially the case for products for which the price elasticity is high in the poorer country.

\section{Distribution sector}

All goods have a local nontradable input component, namely the wholesale and retail distribution component. The price of the very same good will be lower in a country where distribution cost are lower due to lower overall wage level and rents. Large productivity gains in the tradable sector may lead to a rise in distribution costs, implying a rise in the price of consumer goods if productivity does not change in the distribution sector.

\section{External Factors and Economic Structures}

\section{Oil Prices}

Changes in oil prices may influence countries very differently if they have different economic structures. Despite profound economic restructuring and modernisation, the economies of the former Eastern bloc remain very oil intensive. The most oil intensive economies, namely Bulgaria, Estonia, Lithuania and Romania need six to nine times more oil to produce the same amount of GDP than Western European countries, although these figures almost halved from 1991 to 2004. In addition, the transition economies (except for the Czech Republic, Poland and Slovenia) import considerably more oil per unit of GDP than the euro area average. 
The implications are twofold. First, a rise in the price of oil has a larger impact on production costs. Consequently, producer prices are bound to increase faster than in the euro area, which may fuel domestic inflation for domestically produced and consumed goods. It also causes losses in competitiveness and a deterioration of the trade balance. A correction of the trade balance could then lead to a nominal depreciation, which, in a second round, will lead to higher imported and thus overall inflation.

There is also a direct feedback to the consumer price index, which is determined by the share of fuel products in the HICP, and from a broader perspective, the share of energy products (including heating oil and gas, the price of which are related to oil price movements) in the HICP. While fuel accounts for a similar proportion of the HICP in the transition economies and in the euro area (with the exception of Estonia and Slovenia), energy items represent a 40 percent to 100 percent larger chunk of the HICP in the transition economies when compared to the euro area average. Clearly, transition economies would react with higher inflation rates to hikes in energy prices.

However, real catching-up also bears further economic restructuring and a convergence of economic structures, which would entail a further fall in oil intensity and in the share of energy in the HICP and in more synchronisation of the reactions to changes in oil prices.

\section{Exchange Rate Pass-Through}

Besides the obvious differences in openness and exchange rate regimes, the exchange rate passthrough can also generate asymmetric responses in inflation rates if economic structures differ. A first strand of the literature stresses the importance of the macroeconomic factors, in particular inflation rates (Taylor, 2000). The higher the inflation rate is, the higher the exchange rate passthrough is thought to be because in a high inflationary environment, prices are adjusted more frequently. Another body of the literature argues that what is crucial for the size of the passthrough is the composition of imports (Campa and Goldberg, 2002). This literature points out that the pass-through is higher for homogenous goods, while it is lower for differentiated goods, where there is more scope for pricing-to-market practices. As a result, poorer countries that import more homogenous goods face higher pass-through than richer countries where the share of manufactured goods in total imports is higher. In addition to that, a shift in the composition of imports towards more differentiated goods occurs with economic development. Hence, the overall 
exchange rate pass-through is expected to be higher in catching-up economies than in developed countries.

Trend Nominal Appreciation - Equivalence or Fallacy?

Nevertheless, the pass-through is expected to decrease in catching-up economic with lower macroeconomic volatility and a shift towards more differentiated imported goods: a given change in the exchange rate will not be reflected in a correspondingly high change in the inflation rate. In contrast to this stands the role of the exchange rate on price levels since for instance an appreciation of the exchange rate will increase the price level of the transition economies expressed in euros. This increase will be immediate and full in the very short-run. In the longer term, the impact depends inversely on the strength of the exchange rate pass-through. A lower pass-through will imply that a nominal appreciation or depreciation would cause a more important increase or decrease in the price level expressed in euros.

It is worthwhile pausing in this context on the equivalence advocated by numerous economists between price level convergence caused by higher productivity-driven inflation rates (BalassaSamuelson) and price level convergence due to the appreciation of the nominal exchange rate. In the standard Balassa-Samuelson framework, PPP holds for tradables, so the change in the price level comes as an increase in non-tradable prices due to productivity gains in the tradable sector. In the case of nominal appreciation, a rise in the price level comes once again from the rise in the price level of non-tradables due to the nominal appreciation, while the prices of tradables remain constant in the foreign currency given that PPP holds.

Nevertheless, if we consider this equivalence more in depth, it quickly turns into a fallacy. Because of the incomplete pass-through to tradable goods, PPP fails to hold for tradable goods and the failure of PPP implies that the real exchange rate of the open sector appreciates. This has two implications. First, an appreciation, which is needed to produce the size of a price level convergence, which equals the one due to the Balassa-Samuelson effect (non-tradable prices) leads to a more pronounced increase in the price level, because the price level of the tradable goods also rises. Second, it worsens competitiveness as the real exchange rate of the tradable goods appreciates. This stands in contrast to the B-S effect, which is competitiveness neutral and where price level convergence comes only through non-tradables. 
The equivalence might be extended to the whole price level because we have seen that tradable goods are also a source of price level convergence. This means that real convergence may also entail an increase in the price level of tradable goods, thanks to a shift to better quality goods and perhaps also to pricing-to-market practices. Now, the question is whether these price increases are fully equivalent to a nominal appreciation. The answer is clearly no for two reasons. From a consumer viewpoint, a nominal appreciation raises the price level of both poor and better quality goods, while this is not the case if price level convergence comes via a mismeasurement of a shift towards high price goods. From the perspective of exporting firms, nominal appreciation worsens the competitiveness of the very same good, while competitiveness is not affected if prices increase because of better quality.

Nevertheless, nominal appreciation could be sustained for some time. In particular, high mark-up sectors could react by squeezing profits. In addition, firms which have large foreign currency denominated liabilities could compensate by narrowing margins via the decrease in their debt's value in domestic currency terms (balance sheet effect).

Yet, price level convergence coming exclusively from a nominal trend appreciation could mean a bumpy road. First, low mark-up sectors will loose out very quickly. Second, even for high markup sectors, mark-ups will be squeezed to zero and/or prices on the exports markets will increase leading to losses in market shares at some point. This hollows out the export sector, which is the main engine of real convergence in transition economies. Also, domestic input prices, like rents, market and non-market services and, importantly, wages would increase in foreign currency terms. Even though this could be compensated by a drop in the price of imported inputs, such increases could prompt the reallocation of economic activity to cheaper locations.

\section{Business Cycles and Economic Structures}

The output gap is usually viewed as an important determinant of inflation rates (see e.g. Honohen and Lane, 2004; Angeloni and Ehrmann, 2004 and Hofmann and Rembsperger, 2005, for euro area countries). However, the link between output gaps and inflation rates is not that obvious because some items such as regulated prices and the prices of those goods that are strongly influenced by external factors may be not connected to domestic output gaps (European Commission, 2006 and Chmielewski and Kot, 2006). 
If we assume that output gaps and inflation rates are related, inflation rates may differ across countries thanks to differences in output gaps, i.e. the position in the business cycles. ${ }^{3}$ With this respect, one may ask two questions. First, are business cycles different across countries? If yes, is there any mechanism at work to correct those divergences? Conventional wisdom holds that factor mobility, labour market flexibility, trade openness and similar economic structures help eliminate asymmetric shocks and generate more business cycle synchronisation if the exchange rate is fixed.

Furthermore, intra-industry trade is found to be a key determinant of business cycle harmonisation (Frankel and Rose, 1998). The higher the share of openness and the more important the share of intra-industry trade in total trade flows, the stronger the synchronisation of business cycles because a slowdown or acceleration in a given sector will equally affect both countries. Frankel and Rose (1998) also argue that intraindustry trade would secure endogenously business cycle synchronisation. Business cycles may be less correlated today, but if the share of intraindustry trade in total trade is high enough, business cycles will become synchronised in the future.

Finally, fiscal policy has recently been found to have a strong impact on business cycle synchronisation. Darvas, Rose and Szapáry (2005) demonstrate for the case of 21 OECD countries that higher fiscal convergence in terms of the government's budget position tends to be linked to higher business cycle synchronisation.

\section{Modelling issues}

\subsection{Variable selection}

\section{Factors related to real convergence}

We seek to cover comprehensively the determinants of inflation due to real convergence. For this purpose, we use the following variables that are available at annual frequency:

- Balassa-Samuelson variable measured by productivity differential growth (D PROD): the difference of productivity growth in the tradable sector versus productivity growth in the nontradable sector is a proxy for the Balassa-Samuelson effect. If the Balassa-Samuelson effect were to hold, the estimated coefficient should be positive. We use a narrow (D_PROD1) and a

\footnotetext{
${ }^{3}$ Oil prices and business cycle divergence clearly has a bearing on the inflation rate as oil price increases are more easily and quickly passed through to consumer prices during periods of strong economic conditions than during times of slow growth. Consequently, a given rise in the price of oil will affect inflation rates differently, if business cycles are not synchronised across countries.
} 
wide definition (D_PROD2) of the productivity differential. In the narrow definition, the nontradables sector is defined as market services, while for the wide definition, all services are used.

- Initial price level taken in natural logarithm (PRICE_LEVEL_LAG): the use of initial price levels could provide and indirect insights with regard to the impact of price level convergence. The price level is used with one year lag and a lower price level in the previous year is expected to generate higher inflation in the following year. Such an effect should not be interpreted as evidence for the Balassa-Samuelson effect but more as evidence of levelling off price levels across the whole spectrum of prices (including goods, market and non-market services).

- Productivity growth in the distribution sector (D_PROD_DISTR): increased efficiency in the distribution sector over increases in unit labour costs should lower prices sold in wholesale and retail distribution outlets.

- Changes in the structure of household consumption: this variables is meant to capture more directly quality effects in the spirit of the extension of Engel's Law. Recall that poorer household tend to spend relatively more on foodstuff and also on goods and services of lower quality. We use four proxies:

1. the change in the share of household energy in the HICP (D_HEN)

2. the change in the share of foodstuff in the HICP (D_FOOD)

3. the change in the share of services in the HICP (D_SERV)

\section{4. the rate of growth of GDP per capita measured in PPP (D_CAP)}

A negative coefficient on measures 1 and 2 would indicate that a decrease in the share of household energy/foodstuff in the final consumption basket (and thus a higher bias towards goods of better quality) is related to higher inflation rates. We would interpret a positive coefficient on measures 3 and 4 in a similar vein.

- The growth rate of regulated service prices (D_REGPRICE): the narrow definition of regulated services are used that excludes household energy and rents. ${ }^{4}$

\footnotetext{
${ }^{4}$ The narrow definition of regulated services was proposed by ECB (2003) and extended by Lünneman and Mathä (2005) and considers the following subcategories as regulated: 1.) refuse collection, 2.) sewerage collection, 3 .) medical and paramedical services, 4.) dental services, 5.) hospital services, 6.) passenger transport by railway,
} 
- The rate of growh of nominal house prices (D_HP)

\section{External factors}

- Changes in the nominal effective exchange rate multiplied by openness (D_NEER_OPEN): as an increase in the exchange rate variable is an appreciation, a negative relation would indicate that nominal currency appreciation (depreciation) would bring down (spark) inflation.

- The growth rate of food prices (D_COMMODITY) multiplied by the share of foodstuff in the HICP to pick changes in food prices

- The growth rate of oil prices (D_OIL)in dollar terms multiplied by the share of household energy in the HICP.

\section{Monetary policy}

The impact of the stance of monetary policy (PRATE) on inflation is captured by the difference between the observed short-term interest rate and the rate implied by an estimated monetary policy reaction function. The reaction function was estimated on quarterly time series for each country and includes the lagged policy rate, the inflation gap (deviation of the inflation rate from its trend computed on the basis of the HP filter) and output gap (deviation of the rate of growth of real GDP from its trend computed on the basis of the HP filter). The reaction functions are estimated using OLS (RATE1) and GMM (RATE2). Annual averages of the quarterly results are calculated for the annual panel estimations. A negative coefficient would indicate that the observed interest rate higher (lower) than the estimated interest rate is associated with a lower (higher) inflation rate. In other words, restrictive monetary policy would decrease inflation while loose monetary policy would result in higher inflation rates.

\section{Other factors}

- The cycle (CYCLE) is measured with the output gap. ${ }^{5}$

- Lagged inflation (P_LAG) that would account for inflation persistence.

7.) postal services, 8.) education and 9.) social protection, 10.) cultural services and 11.) passenger transport by road

\footnotetext{
${ }^{5}$ See Vasicek (2009) for a discussion of the Phillips curve in Central and Eastern Europe.
} 
- Dummy variables that differentiate between euro area and non euro area countries and between countries that implemented inflation targeting and that did not. For instance, Batini et al (2005) argue that inflation targeters have lower inflation rates than non-inflation targeters. The dummy on inflation targeting is interacted with the exchange rate variable given that the size of the exchange rate pass-through should depend on the monetary policy framework. ${ }^{6}$

\subsection{Estimation issues}

\section{Linear panel models}

We first analyse the linear relation between the annual inflation rate and a set of covariates. The estimations are carried out using the Least Square Dummy Variable estimator (LSDV or country fixed effects OLS) with standard errors that are robust to the presence of heteroskedasticity in the residuals. LSDV estimates may give rise to biased estimates if the lagged dependent variable is included on the right hand side. As the lagged dependent variable may be correlated with the error terms, the difference GMM estimator developed by Arellano and Bond (1991) and the more efficient system GMM estimator proposed by Arellano and Bover (1995) are often used in the literature. Nevertheless, GMM estimators are designed for datasets with small T (time) and large $\mathrm{N}$ (cross section) dimensions. In our case, $\mathrm{N}$ and $\mathrm{T}$ are small. For such a case, the correction developed by Kiviet (1995), Bun and Kiviet (2003) and Bun and Carree (2005) for balanced panels and by Bruno $(2005 \mathrm{a}, \mathrm{b})$ for unbalanced panels seems more appropriate. We therefore apply the Kiviet estimator of Bruno (2005a,b) to check the robustness of our LSDV estimates.

\section{Bayesian model averaging}

Bayesian model averaging provides a convenient framework to carry out a very comprehensive sensitivity analysis of a given dependent variable with regard to other explanatory variables. More specifically, the approach advocated by Sala-i-Martin, Doppelhofer and Miller (2004) investigates not whether any given explanatory variable is robust to the inclusion of other variables, but investigatse the probability with which any given variable would be included in the estimated model space. This approach requires the estimation of all possible combinations of the candidate

\footnotetext{
${ }^{6}$ It would be also desirable to include variables that capture the level and changes in product and labour market regulations (Bulir and Hurnik, 2008) and structural reforms (Barlow, 2009). Nevertheless, the Product and Labour Market Regulation indicators (PMR and LMR) used for instance in Bulir and Hurnik (2008) for euro area countries are not available for most CEE countries. In addition, these data are collected once every three years. By contrast, the indicators on structural reforms used in Barlow (2009) are only available for CEE countries but not for Western European countries.
} 
explanatory variables (of number $\mathrm{K}$ ) that is usually quantified as $2^{K}$. If the number of models to be estimated is so high that currently available computer power cannot cope with the estimations, a subset of regressions can be estimated using for instance the Markov-Chain Monte-Carlo Model Composition or a stochastic search variable selection or other forms of model sampling such as the random sampling procedure employed in Sala-i-Martin, Doppelhofer and Miller (2004). We estimate the whole model space as the number of potential regressors at hand is limited and allows the estimation of all possible combinations.

Bayesian averaging of classical estimates (BACE) first determines the posterior probability attributed to each single model $M_{j}$ that includes the given variable and conditioned on the underlying dataset $\left(P\left(M_{j} \mid y\right)\right)$.

$$
P\left(M_{j} \mid y\right)=\frac{P\left(M_{j}\right) T^{-k_{j} / 2} S S E_{j}^{-T / 2}}{\sum_{i=1}^{2^{K}} P\left(M_{i}\right) T^{-k_{i} / 2} S S E_{i}^{-T / 2}}
$$

where SSE is the sum of squared residuals, $\mathrm{T}$ is the number of observations, $\mathrm{k}$ denotes the number of explanatory variables included in the specific model and $\mathrm{K}$ is the number of all explanatory variables considered. Expression (3) shows the extent to which any given model contributes to explaining the dependent variable as compared to the other models.

Expression (3) is then summed up for the models that contain the variable of interest to obtain the posterior inclusion probability of this variable. The posterior inclusion probability are then compared to the prior inclusion probability, which is $1 / 2$ if all possible combinations are considered. If the posterior inclusion probability is higher than the prior inclusion probability, one can conclude that the specific variable will be included in the model.

The posterior mean conditional on inclusion $(E(\beta \mid y))$ is the average of the individual OLS estimates weighted by $P\left(M_{j} \mid y\right)$. The unconditional posterior mean considers all regressions, even those without the variable of interest. Hence, the unconditional posterior mean of any given variable can be derived as the product of the conditional posterior mean and the posterior inclusion probability.

The posterior variance of $\beta(\operatorname{Var}(\beta \mid y))$ can be calculated as follows: 


$$
\operatorname{Var}(\beta \mid y)=\sum_{j=1}^{2^{K}} P\left(M_{j} \mid y\right) \operatorname{Var}\left(\beta \mid y, M_{j}\right)+\sum_{j=1}^{2^{K}} P\left(M_{j} \mid y\right)\left(\hat{\beta}_{j}-E(\beta \mid y)\right)^{2}
$$

The posterior mean and the square root of the variance (standard error) conditional on inclusion can be used to determine the significance of the individual variables upon inclusion.

\section{Non-linear specification}

Inflation rates may be connected to the explanatory variables in a non-linear fashion. We compare our linear estimates to two or three-regime models in which the explanatory variables are allowed to have a nob-linear effect on the inflation rate as a function of a threshold variable with the threshold values of the threshold variable being determined endogenously along the lines of the two-regime and three-regime threshold models proposed by Hansen (1999):

$$
\begin{aligned}
& P_{t}=\left\{\begin{array}{llc}
\alpha_{1}+\beta_{1} \cdot Y_{t}+\bar{\theta} \bar{Z}+\varepsilon_{t} & \text { if } & T \leq \rho \\
\alpha_{2}+\beta_{2} \cdot Y_{t}+\bar{\theta} \bar{Z}+\varepsilon_{t} & \text { if } & T>\rho
\end{array}\right. \\
& P_{t}=\left\{\begin{array}{llc}
\alpha_{1}+\beta_{1} \cdot Y_{t}+\bar{\theta} \bar{Z}+\varepsilon_{t} & \text { if } & T_{1} \leq \rho \\
\alpha_{2}+\beta_{2} \cdot Y_{t}+\bar{\theta} \bar{Z}+\varepsilon_{t} & \text { if } & T_{2} \geq \rho>T_{1} \\
\alpha_{3}+\beta_{3} \cdot Y_{t}+\bar{\theta} \bar{Z}+\varepsilon_{t} & \text { if } & \rho>T_{2}
\end{array}\right.
\end{aligned}
$$

where $\mathrm{T}, \mathrm{T} 1$ and $\mathrm{T} 2$ are the threshold values of the threshold variable $\rho$. In accordance with Hansen (1999), linear and non-linear models are selected as follows. We first estimate the linear model and the two-regime model. A grid search with steps of $1 \%$ of the distribution is carried out to find the value of the threshold variable that minimizes the sum of squared residuals of the estimated two-regime model. Hansen (1999) shows that $\beta_{1}=\beta_{2}$ and $\beta_{1}=\beta_{2}=\beta_{3}$ can be tested using a likelihood ratio test and he proposes to derive the distribution of the test statistic via bootstrapping with repeated random draws with replacements (Hansen, 1999), as it does not follow a standard asymptotic distribution.

\section{Results}

The empirical analysis is carried out for 23 countries of the European Union for the period from 1998 to 2007. Cyprus, Malta and Romania are excluded from our sample because house price data are not available for these countries. We also drop Luxembourg from the sample because it turns out to be an outlier in empirical analyses. 
We seek to control for alternative variable definitions and measurements as set out earlier. Hence, the estimated alternative specifications include two measures of the Balassa-Samuelson effect (D_PROD1, D_PROD2), four measures of the change in the composition of household consumption patterns (D_HEN, D_FOOD, D_SERV, D_CAP) that aim to proxy the extension of Engel's Law and two measures of the monetary policy stance.

\section{Factors related to catching-up}

Results obtained using the LSDV estimator, displayed in Table 1a, suggest that annual inflation rates in the European Union are associated with changes in factors related to economic catchingup. First, the initial price level is negatively correlated with inflation rates implying that lower price levels and higher inflation rates go hand in hand. Second, inflation and regulated prices exhibit a strong positive correlation. Finally, growth in nominal house prices appears to affect positively inflation rates, even though the effect is small in magnitude. By contrast, the BalassaSamuelson variable is always insignificant at conventional significance levels and is mostly negative. Concerning factors aimed at capturing the extension of Engel's Law, changes in the share of household energy (D_HEN) has the expected negative sign but the coefficients are never significant. Changes in the share of services (D_SERV) also have the expected positive relation to the inflation rate, but they again are statistically insignificant. Finally, the two other alternative measures are neither correctly signed nor significant. Overall, these results are robust to alternative model specifications (Table 1a) in terms of variable definition and whether or not time fixed effects or a linear trend are added on top of country fixed effects.

As shown in Table 1b, the results do not change if the estimations are carried out using the bias corrected LSDV estimator of Bruno (2005a,b): initial price levels, house and regulated prices are found to be important drivers of inflation. The size of the coefficient estimates of these variables is very close to those obtained in Table 1a. At the same time, the Balassa-Samuelson variables remain insiginificant even though they now have a positive sign (with very small coefficient estimates) for most of the time. Variables that capture the extended Engel's Law are found to be statistically not significant.

Table 1c reports a set of additional robustness checks. First, house prices and regulated prices are dropped (equation 1): this allows to increase the number of observations as regulated price series start later than 1998 for some countries and as we can now include Romania in the sample. The 
results for the initial price level and the variable D_HEN are unchanged. Second, productivity growth in the distribution sector (D_PROD_DISTR) is added to the baseline specifications: this eliminates the observations for 2007 as D_PROD_DISTR is not available for that year. The only difference to the earlier results is that the size of the coefficient estimate on the initial price level increases substantially. Third, dummies for euro area membership and inflation targeting frameworks are added to the baseline specification and the dummy for inflation targeting is interacted with the exchange rate variable. The results are robust to these changes. The only exception is the house price variable that becomes insignificant when the interaction terms are used.

An additional robustness check for the annual dataset consists in the use of Bayesian model averaging. As shown in Table 1d, the three variables that have posterior inclusion probabilities higher than the 0.5 prior inclusion probability are: the initial price level, regulated prices and house prices. The means conditional on inclusion are very close to the coefficient estimates obtained in single equation models. On the other hand, the Balassa-Samuelson variable and the variable that measures the extension of Engel's Law have posterior inclusion probabilities below 0.5 and thus do not enter the model space.

We finally look at possible non-linear effects in the ways of how the factors analysed thus far influence annual inflation rates. Two thresholds variables were considered: the initial price level and the growth rate of GDP per capita measured in PPS. When we allow variables related to catching-up to behave in a nonlinear fashion as a function of the initial price level, Table 2a suggests that two variables exhibit considerable non-linear patterns. First, regulated prices are found to have a larger impact if the initial price level is low but this impact becomes lower for higher price levels. Second, a lower initial price level has a larger impact on the inflation rate if it is low and the impact decreases with the rise in the price level. When non-linearity is a function of GDP per capita growth, estimation results reported in Table $2 \mathrm{~b}$ indicate that price level convergence is a little smaller if GDP per capita growth is around 8 percent per annum. This is not a very intitutive result and further research would be needed to investigate this issue more in depth. Another finding is that one variable that proxies the extended Engel's Law (D_HEN) has the expected strong negative impact on inflation rates if GDP per capita growth is high. This variable is not significant if GDP per capita growth is low. 
Table 1e presents results that are based on multiyear averages. The variables were averaged for the periods 1999 to 2002 and 2003 to 2007 . While constructing multiyear averages decreases the number of observations, such data may be informative about more longer-term effects of the factors related to catching-up. The results indicate that regulated prices and house prices are very robust drivers of inflation rates and that the price level variable is somewhat sensitive to alternative model specifications. The Balassa-Samuelson variable has the wrong negative sign and is statistically significant in half of the cases. The variables for the extended Engel's Law are all correctly signed but are imprecisely estimated with large standard errors.

\section{Other factors}

After having looked at how catching-up influences inflation rates in the European Union, we now take a good look at the other factor. First, inflation is very persistent given the lagged inflation rate is very significant in all specification. Second, commodity prices have a strong positive influence on the inflation rate. Third, cyclical fluctuations measured by the output gap have a strong positive association with inflation. Upturns are associated with higher inflations whereas downturns are linked to lower inflation rates. Fourth, rising (declining) oil prices do not seem to result in higher (lower) inflation rates. Fifth, the nominal exchange rate variable (that controls for openness) has a strong negative impact on inflation implying that a nominal appreciation is linked to a decrease in the inflation rate whereas a nominal depreciation goes in tandem with a higher inflation rate. Nevertheless, the size of the coefficient estimates suggests that the pass-through from the exchange rate to inflation is far too be complete. Sixth, the inclusion of dummies for euro area membership and the use of inflation targeting tells us (Table 1c) that being member of the euro area or having inflation targeting decreases inflation even though these effects are not statistically significant. The distinction between inflation targeters and non-inflation targeters indicates that the impact of the exchange rate on inflation is considerable lower in the former group of countries. Finally, the variable that measures monetary policy stance has positive coefficient estimates that is rather counterintutitive as it suggests that tigher (looser) monetary policy increases (decreases) inflation. Nevertheless, the coefficient estimates are very unstable and often insignificant across various estimation results.

Generally speaking, these results are very robust to alternative model specifications, estimation methods and Bayesian model averaging. 
We also analyse non-linearity for the set of variables discussed above using the inflation rate as the threshold variable. Table 1c shows that if the reaction of inflation to the cycle is stronger is inflation rates are higher. This indeed suggests a flattening of the Phillips curve with a decline in the inflation rate. The results also show that inflation is more persistant for higher inflation rates and that commodity prices have a stronger influence on inflation in a higher inflation environment.

Table 1a. Estimation results based on the LSDV estimator, 1998-2007 Dependent variable $=$ inflation rate $(P)$

\begin{tabular}{|c|c|c|c|c|c|c|c|c|}
\hline & eq 1 & eq 2 & eq 3 & eq 4 & eq 5 & eq 6 & eq 7 & eq 8 \\
\hline P_LAG & $0.234 * *$ & $0.214 * *$ & $0.224 * *$ & $0.235 * *$ & $0.231 * *$ & $0.235 * *$ & $0.230 * *$ & $0.204 * *$ \\
\hline D_COMMODITY & $0.172 * *$ & $0.391 * *$ & $0.130 *$ & $0.172 * *$ & $0.164 * *$ & $0.169 * *$ & $0.166 * *$ & $0.160 * *$ \\
\hline D_NEER_OPEN & $-0.056^{* *}$ & $-0.048 * *$ & $-0.06^{* *}$ & $-0.056 * *$ & $-0.058 * *$ & $-0.056^{* *}$ & $-0.057 * *$ & $-0.062 * *$ \\
\hline D_OIL & -0.038 & -0.042 & -0.051 & -0.038 & -0.036 & -0.038 & -0.035 & -0.040 \\
\hline PRICE_LEVEL_LAG & $-4.978 * *$ & $-5.881 * *$ & $-5.700 * *$ & $-4.973 * *$ & $-5.045 * *$ & $-4.882 * *$ & $-4.865 * *$ & $-3.722 * *$ \\
\hline D_PRODD1 & -0.001 & 0.006 & 0.002 & & -0.005 & -0.001 & -0.001 & -0.001 \\
\hline D_PROD2 & & & & 0.003 & & & & \\
\hline D_HEN & -0.036 & -0.083 & -0.035 & -0.038 & & & & -0.009 \\
\hline D_FOOD & & & & & 0.034 & & & \\
\hline D_SERV & & & & & & 0.013 & & \\
\hline D_CAP & & & & & & & -0.014 & \\
\hline 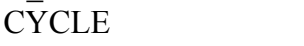 & $0.293 * *$ & $0.174 * *$ & $0.306 * *$ & $0.293 * *$ & $0.297 * *$ & $0.290 * *$ & $0.304 * *$ & $0.305 * *$ \\
\hline PRATE1 & $0.141 *$ & 0.123 & 0.13 & $0.142 *$ & $0.151 *$ & $0.144^{*}$ & $0.144 *$ & \\
\hline PRATE2 & & & & & & & & $0.247 * *$ \\
\hline D_HP & $0.016^{*}$ & $0.02 * *$ & $0.014^{*}$ & $0.016^{*}$ & $0.016^{*}$ & $0.017 *$ & $0.017^{*}$ & $0.018 * *$ \\
\hline D_REGPRICE & $0.380 * *$ & $0.376^{* *}$ & $0.381 * *$ & $0.379 * *$ & $0.382 * *$ & $0.380 * *$ & $0.382 * *$ & $0.364 * *$ \\
\hline LINEAR TREND & & & 0.047 & & & & & \\
\hline Country fixed effect & YES & YES & YES & YES & YES & YES & YES & YES \\
\hline Time fixed effect & $\mathrm{NO}$ & YES & NO & $\mathrm{NO}$ & NO & NO & $\mathrm{NO}$ & NO \\
\hline Adj. R-squared & 0.781 & 0.795 & 0.782 & 0.781 & 0.782 & 0.781 & 0.781 & 0.793 \\
\hline No obs & 196 & 196 & 196 & 196 & 196 & 196 & 196 & 196 \\
\hline countries & 23 & 23 & 23 & 23 & 23 & 23 & 23 & 23 \\
\hline
\end{tabular}

Note: $*$ and $* *$ denote statistical significance at the $10 \%$ and $5 \%$ levels. 
Table 1b. Estimation results based on the bias-corrected LSDV estimator, 1998-2007 Dependent variable $=$ inflation rate $(P)$

\begin{tabular}{|c|c|c|c|c|c|c|}
\hline & eq_1 & eq 3 & eq 4 & eq 5 & eq 6 & eq 7 \\
\hline P_LAG & $0.299 * *$ & $0.299 * *$ & $0.301 * *$ & $0.296 * *$ & $0.300 * *$ & $0.295 * *$ \\
\hline D_COMMODITY & $0.180 * *$ & $0.141 * *$ & $0.181 * *$ & $0.173 * *$ & $0.177 * *$ & $0.174 * *$ \\
\hline D_NEER_OPEN & $-0.059 * *$ & $-0.062 * *$ & $-0.058 * *$ & $-0.0609 * *$ & $-0.058 * *$ & $-0.059 * *$ \\
\hline $\mathrm{D}^{-} \mathrm{OIL}$ & -0.036 & -0.044 & -0.035 & -0.034 & -0.036 & -0.035 \\
\hline PRICE_LEVEL_LAG & $-4.565^{*}$ & $-5.068 * *$ & $-4.565^{*}$ & $-4.601 *$ & $-4.451 *$ & $-4.476^{*}$ \\
\hline D_PROD1 & 0.001 & 0.005 & & -0.002 & 0.001 & 0.0002 \\
\hline D_PROD2 & & & 0.005 & & & \\
\hline D_HEN & -0.039 & -0.0422 & -0.0417 & & & \\
\hline D_FOOD & & & & 0.027 & & \\
\hline D_SERV & & & & & 0.016 & \\
\hline D_CAP & & & & & & -0.007 \\
\hline $\mathrm{C} \bar{Y} \mathrm{CLE}$ & $0.288^{* *}$ & $0.304 * *$ & $0.287 * *$ & $0.291 * *$ & $0.283 * *$ & $0.293 * *$ \\
\hline PRATE1 & $0.141^{*}$ & $0.129 *$ & $0.141^{*}$ & $0.149 *$ & $0.143^{*}$ & $0.144^{*}$ \\
\hline D_HP & $0.017 *$ & $0.015^{* *}$ & $0.016^{*}$ & $0.017 * *$ & $0.017 * *$ & $0.017 * *$ \\
\hline D_REGPRICE & $0.366^{* *}$ & $0.363 * *$ & $0.366^{* *}$ & $0.369 * *$ & $0.367 * *$ & $0.369 * *$ \\
\hline LINEAR TREND & & 0.036 & & & & \\
\hline No obs & 196 & 196 & 196 & 196 & 196 & 196 \\
\hline countries & 23 & 23 & 23 & 23 & 23 & 23 \\
\hline
\end{tabular}

Note: $*$ and $* *$ denote statistical significance at the $10 \%$ and $5 \%$ levels.

Table 1c. Estimation results based on the LSDV estimator, 1998-2007 Dependent variable $=$ inflation rate $(P)$ Robustness check

\begin{tabular}{|c|c|c|c|c|c|c|c|c|}
\hline & Eq1 & & Eq2 & & Eq3 & & $\mathrm{Eq} 4$ & \\
\hline P_LAG & 0.584 & $* *$ & 0.266 & $* *$ & 0.245 & $* *$ & 0.203 & $* *$ \\
\hline D_COMMODITY PRICES & 0.237 & $* *$ & 0.194 & $* *$ & 0.171 & $* *$ & 0.195 & $* *$ \\
\hline D_NEER_OPEN & -0.097 & $* *$ & -0.092 & $* *$ & -0.053 & $* *$ & & \\
\hline D_NEER_OPEN*DUMMY_IT & & & & & & & -0.008 & \\
\hline D_NEER_OPEN*(1-DUMMY_IT) & & & & & & & -0.109 & $* *$ \\
\hline D_OIL & 0.07 & & -0.045 & & -0.029 & & -0.054 & \\
\hline PRICE_LEVEL_LAG & -5.169 & * & -10.052 & $* *$ & -4.478 & $* *$ & -5.658 & $* *$ \\
\hline D_PROD1 & -0.001 & & 0.010 & & -0.005 & & -0.002 & \\
\hline D_HEN & -0.053 & & -0.102 & & -0.040 & & -0.041 & \\
\hline CYCLE & 0.276 & $* *$ & 0.273 & $* *$ & 0.303 & $* *$ & 0.258 & $* *$ \\
\hline PRATE1 & -0.056 & & 0.065 & & 0.142 & $*$ & 0.132 & $*$ \\
\hline D_HP & & & $0.022 * *$ & $* *$ & 0.015 & $*$ & 0.012 & \\
\hline D_REGPRICE & & & 0.306 & $* *$ & 0.366 & $* *$ & 0.396 & $* *$ \\
\hline D_PROD_DISTR & & & 0.022 & & & & & \\
\hline DUMMY_EURO & & & & & -0.072 & & & \\
\hline DUMMY_IT & & & & & -0.869 & & & \\
\hline LINEAR TREND & & & & & & & & \\
\hline Country fixed effect & YES & & YES & & YES & & YES & \\
\hline Time fixed effect & NO & & NO & & NO & & NO & \\
\hline adj R2 & 0.802 & & 0.765 & & 0.780 & & 0.788 & \\
\hline Obs & 210 & & 151 & & 196 & & 196 & \\
\hline Countries & 24 & & 23 & & 23 & & 23 & \\
\hline
\end{tabular}

Note: $*$ and $* *$ denote statistical significance at the $10 \%$ and $5 \%$ levels. 
Table 1d. Bayesian model averaging, 1998-2007

Dependent variable $=$ inflation rate $(P)$

\begin{tabular}{|c|c|c|c|c|c|c|c|c|}
\hline & \multicolumn{4}{|c|}{ Country fixed effects } & \multicolumn{4}{|c|}{ Country and time fixed effects } \\
\hline & P.I.B. & $\begin{array}{l}\text { Mean } \\
\text { C.O.I }\end{array}$ & $\begin{array}{c}\text { Mean } \\
\text { U.C. }\end{array}$ & \begin{tabular}{c|} 
s.e. \\
C.O.I
\end{tabular} & P.I.B. & $\begin{array}{l}\text { Mean } \\
\text { C.O.I }\end{array}$ & $\begin{array}{c}\text { Mean } \\
\text { UC }\end{array}$ & $\begin{array}{l}\text { s.e. } \\
\text { C.O.I }\end{array}$ \\
\hline P_LAG & 0.992 & 0.223 & 0.221 & 0.067 & 0.941 & 0.180 & 0.169 & 0.067 \\
\hline D_COMMODITY PRICES & 0.966 & 0.167 & 0.162 & 0.046 & 0.773 & 0.284 & 0.220 & 0.165 \\
\hline D_NEER_OPEN & 0.716 & -0.042 & -0.030 & 0.019 & 0.656 & -0.036 & -0.024 & 0.018 \\
\hline D_OIL & 0.106 & -0.004 & 0.000 & 0.005 & 0.082 & -0.004 & 0.000 & 0.010 \\
\hline PR्̄ICE_LEVEL_LAG & 0.844 & -4.253 & -3.591 & 5.429 & 0.813 & -4.405 & -3.583 & 6.833 \\
\hline D_PRODD1 & 0.065 & $-2.1 \mathrm{E}-05$ & $-1.4 \mathrm{E}-06$ & 0.001 & 0.067 & $2.8 \mathrm{E}-04$ & $1.9 \mathrm{E}-05$ & 0.001 \\
\hline D_HEN & 0.087 & -0.005 & 0.000 & 0.010 & 0.124 & -0.012 & -0.001 & 0.012 \\
\hline 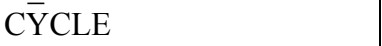 & 1.000 & 0.298 & 0.298 & 0.052 & 0.894 & 0.159 & 0.142 & 0.057 \\
\hline PRATE1 & 0.509 & 0.082 & 0.042 & 0.049 & 0.448 & 0.071 & 0.032 & 0.041 \\
\hline D_HP & 0.647 & 0.012 & 0.008 & 0.006 & 0.940 & 0.023 & 0.022 & 0.009 \\
\hline D_REGPRICE & 1.000 & 0.376 & 0.376 & 0.054 & 1.000 & 0.384 & 0.384 & 0.052 \\
\hline regressions run & 2037 & & & & & & & \\
\hline prior inclusion probability & 0.50 & & & & & & & \\
\hline
\end{tabular}

Notes: bold figures indicate that the estimated posterior inclusion probability is higher than the prior inclusion probability of 0.5 P.I.B = posterior inclusion probability, Mean C.O.I=mean conditional on inclusion, Mean U.C.=unconditional mean, s.e. C.O.I. =standard error conditional on inclusion.

Table 1e. Cross section regressions, 4-year averages

\section{Dependent variable: inflation rate}

\begin{tabular}{|c|c|c|c|c|c|c|c|c|}
\hline & Eq1 & & $\mathrm{Eq} 2$ & & Eq3 & & $\mathrm{Eq} 4$ & \\
\hline PRICE_LEVEL & -8.393 & ** & -6.892 & & -6.488 & & -7.711 & $* *$ \\
\hline D_REGPRICE & 0.347 & $* *$ & 0.368 & $* *$ & 0.353 & $* *$ & 0.294 & $* *$ \\
\hline D_HP & 0.130 & $* *$ & 0.132 & $* *$ & 0.134 & $* *$ & 0.106 & $* *$ \\
\hline D_PROD1 & -0.121 & $*$ & -0.070 & & -0.068 & & -0.145 & $* *$ \\
\hline D_HEN & -0.979 & $*$ & & & & & & \\
\hline D_FOOD & & & -0.397 & & & & & \\
\hline D_SERV & & & & & 0.356 & & & \\
\hline D_CAP & & & & & & & 0.122 & \\
\hline Adj. R-squared & 0.822 & & 0.816 & & 0.835 & & 0.812 & \\
\hline Obs & 45 & & 45 & & 45 & & 45 & \\
\hline No of countries & 23 & & 23 & & 23 & & 23 & \\
\hline
\end{tabular}

Note: $*$ and $* *$ denote statistical significance at the $10 \%$ and $5 \%$ levels. 
Table 2a. Non-linear effects related to catching-up, 1998-2007

Dependent variable $=$ inflation rate $(P)$

Threshold variable $=$ price level $(P$

\begin{tabular}{|c|c|c|c|c|c|c|c|c|}
\hline & \multicolumn{2}{|c|}{ D_HEN } & \multicolumn{2}{|c|}{ D_SERV } & \multicolumn{2}{|c|}{ D_FOOD } & \multicolumn{2}{|c|}{ D_CAP } \\
\hline \multicolumn{9}{|c|}{ Test of non-linearity } \\
\hline & p-value & & p-value & & p-value & & p-value & \\
\hline H0: lin vs.H1: 2-reg & 0.000 & & 0.000 & & 0.000 & & 0.000 & \\
\hline H1: 2-reg vs.H2: 3-reg & 0.022 & & 0.012 & & 0.010 & & 0.094 & \\
\hline Threshold No. 1 & 83.3 & 0.460 & 51.2 & 0.200 & 51.2 & 0.200 & 83.3 & 0.46 \\
\hline Threshold No. 2 & 100.9 & 0.670 & 98.9 & 0.580 & 98.9 & 0.580 & 100.9 & 0.67 \\
\hline \multicolumn{9}{|c|}{ Coefficient estimates } \\
\hline \multicolumn{9}{|c|}{ LINEAR VARIABLES } \\
\hline P LAG & 0.156 & $* *$ & 0.119 & $*$ & 0.120 & $* *$ & 0.143 & $* *$ \\
\hline D' COMMODITY PRICES & 0.169 & $* *$ & 0.162 & $* *$ & 0.164 & $* *$ & 0.149 & $* *$ \\
\hline D_NEER_OPEN & -0.043 & $*$ & -0.032 & & -0.031 & & -0.054 & $* *$ \\
\hline D_OIL & -0.038 & & -0.048 & & -0.047 & & -0.034 & \\
\hline CȲ CLE & 0.295 & $* *$ & 0.268 & $* *$ & 0.278 & $* *$ & 0.324 & $* *$ \\
\hline D HP & 0.017 & ** & 0.021 & $* *$ & 0.020 & $* *$ & 0.018 & $* *$ \\
\hline PRATE1 & 0.115 & & 0.137 & $* *$ & 0.126 & $* *$ & 0.126 & \\
\hline \multicolumn{9}{|c|}{ NON-LINEAR VARIABLES } \\
\hline \multicolumn{9}{|c|}{ LOW PRICE LEVEL REGIME } \\
\hline D_REGPRICE & 0.480 & $* *$ & 0.457 & $* *$ & 0.464 & $* *$ & 0.488 & $* *$ \\
\hline PRICE_LEVEL_LAG & -4.551 & $* *$ & -0.222 & & 0.002 & & -4.707 & $* *$ \\
\hline D_SHARE & -0.087 & & 0.056 & & -0.042 & & 0.004 & \\
\hline PRODO1 & 0.013 & & -0.038 & & -0.036 & & 0.008 & \\
\hline \multicolumn{9}{|c|}{ MIDDLE PRICE LEVEL REGIME } \\
\hline D_REGPRICE & 0.198 & $* *$ & 0.539 & $* *$ & 0.536 & $* *$ & 0.192 & $* *$ \\
\hline PR्RICE_LEVEL_LAG & -4.098 & $* *$ & -0.802 & & -0.568 & & -4.169 & $* *$ \\
\hline D_SHĀRE & 0.405 & $*$ & -0.036 & & 0.041 & & -0.036 & \\
\hline PRODO1 & -0.115 & $* *$ & 0.026 & & 0.029 & & -0.128 & $* *$ \\
\hline \multicolumn{9}{|c|}{ HIGH PRICE LEVEL REGIME } \\
\hline D_REGPRICE & 0.120 & $*$ & 0.152 & $* *$ & 0.158 & $* *$ & 0.128 & $* *$ \\
\hline PR्̄ICE_LEVEL_LAG & -4.195 & $* *$ & -0.735 & & -0.492 & & -4.248 & $* *$ \\
\hline D_SHĀRE & -0.142 & & -0.197 & $*$ & 0.056 & & -0.095 & $* *$ \\
\hline PRODD1 & -0.004 & & -0.007 & & 0.000 & & 0.020 & \\
\hline Adj. R-squared & 0.812 & & 0.824 & & 0.822 & & 0.813 & \\
\hline OBS & 196 & & 196 & & 196 & & 196 & \\
\hline No. of countries & 23 & & 23 & & 23 & & 23 & \\
\hline
\end{tabular}

Note: $*$ and $* *$ denote statistical significance at the $10 \%$ and $5 \%$ levels. 
Table 2b. Non-linear effects related to non-catching-up factors, 1998-2007 Dependent variable $=$ inflation rate $(P)$

Threshold variable $=$ GDP per capita $($ in $P P P)$ growth rates

\begin{tabular}{|c|c|c|c|c|c|c|}
\hline & \multicolumn{6}{|c|}{ D_SHARE= } \\
\hline & \multicolumn{2}{|c|}{ D_HEN } & \multicolumn{2}{|c|}{ D_SERV } & D_FOOD & D_CAP \\
\hline \multicolumn{7}{|c|}{ Test of non-linearity } \\
\hline & \multicolumn{2}{|c|}{ p-value } & \multicolumn{2}{|l|}{$\mathrm{p}$-value } & \multirow[b]{2}{*}{0.292} & \multirow[b]{2}{*}{0.156} \\
\hline H0: lin vs.H1: 2-reg & \multicolumn{2}{|l|}{0.080} & \multicolumn{2}{|l|}{0.044} & & \\
\hline H1: 2-reg vs.H2: 3-reg & 0.218 & & 0.118 & & \multirow[t]{2}{*}{0.072} & \multirow[t]{2}{*}{0.480} \\
\hline Threshold & 7.761 & & 8.033 & & & \\
\hline \multicolumn{7}{|c|}{ Coefficient estimates } \\
\hline \multicolumn{7}{|c|}{ LINEAR VARIABLES } \\
\hline P_LAG & 0.265 & $* *$ & 0.238 & $* *$ & & \\
\hline D_COMMODITY PRICES & 0.173 & $* *$ & 0.173 & $* *$ & & \\
\hline D_NEER_OPEN & -0.058 & $* *$ & -0.057 & $* *$ & & \\
\hline D_OIL & -0.028 & & -0.054 & & & \\
\hline CYCLE & 0.259 & $* *$ & 0.246 & $* *$ & & \\
\hline D_HP & 0.018 & $* *$ & 0.012 & & & \\
\hline PRATE1 & 0.157 & $*$ & 0.137 & $*$ & & \\
\hline D_REGPRICE & 0.373 & $* *$ & 0.37 & $* *$ & & \\
\hline PROD1 & -0.007 & & -0.006 & & & \\
\hline \multicolumn{7}{|c|}{ NON-LINEAR VARIABLES } \\
\hline \multicolumn{7}{|c|}{ LOW GDP PER CAPITA GROWTH REGIME } \\
\hline D_HEN & 0.081 & & 0.054 & & & \\
\hline PR्̄ICE_LEVEL_LAG & -4.731 & $* *$ & -5.284 & $* *$ & & \\
\hline \multicolumn{7}{|c|}{ HIGH GDP PER CAPITA GROWTH REGIME } \\
\hline D_HEN & -0.351 & $*$ & -0.232 & & & \\
\hline PRICE_LEVEL_LAG & -4.669 & $* *$ & -5.048 & $* *$ & & \\
\hline Adj. R-squared & 0.789 & & 0.792 & & & \\
\hline OBS & 196 & & 196 & & & \\
\hline No. of countries & 23 & & 23 & & & \\
\hline
\end{tabular}

Note: ${ }^{*}$ and $* *$ denote statistical significance at the $10 \%$ and $5 \%$ levels. 
Table 2c. Non-linear effects related to non-catching-up factors, 1998-2007

Dependent variable $=$ inflation rate $(P)$

Threshold variable $=$ inflation rate $/$ price level $(P$

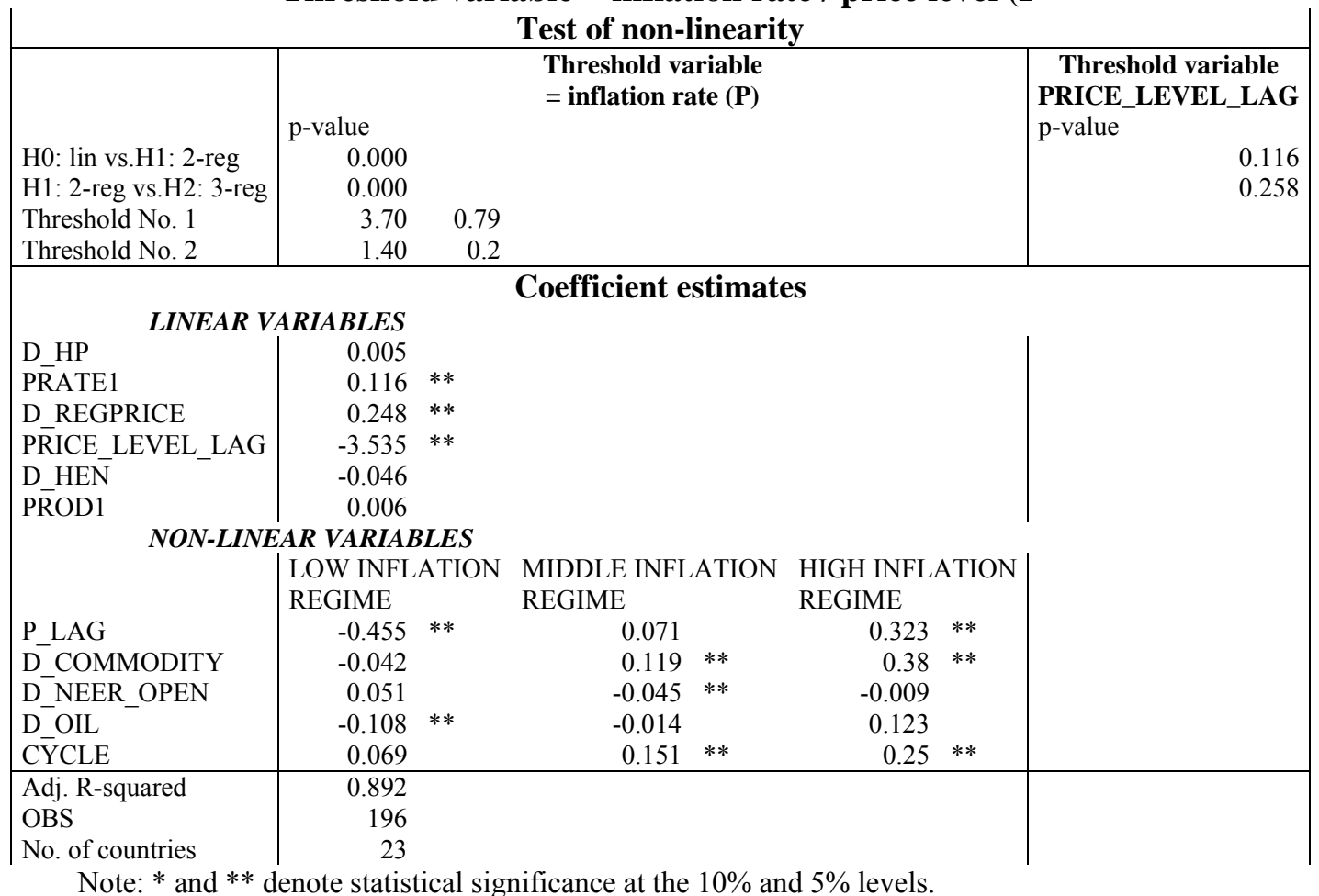

\section{Conclusions}

In this study, we carried out an empirical investigation on the drivers of annual inflation rates in the European Union. Using a variety of econometric estimation methods, we showed that the Balassa-Samuelson effect is not an important driver of inflation rates. Instead, we argued that economic catching-up can lead to a shift in consumption patterns of households. Richer households tend to consume higher quality goods (quality effect), less energy and foodstuff and more services (composition and demand-side effect). We referred to this as the eextension of Engel's Law. Higher wages could (but need not) increase the price of domestically produced and consumed goods and the prices of all goods and services via more expensive wholesaling and retailing. Our estimation results showed that initially lower prices and regulated prices strongly affect inflation outcomes in a nonlinear manner and that the extension of Engel's Law might hold during periods of very fast growth. We interpret these results as a sign that price level convergence comes from goods, market and non-makret service prices. 
Furthermore, we find that the Phillips curve flattens with a decline in the inflation rate, that inflation is more persistant and that commodity prices have a stronger effect on inflation in a higher inflation environment. Our results also suggested that while nominal exchange rate movements have a strong impact on inflation, the pass-through is not complete and the passthrough is more important for non-inflation targeter countries.

\section{References}

Ahnert, H. and G. Kenny (2004), "Quality adjustment of European price statistics and the role for hedonics", ECB occasional paper series No. 15.

Angeloni, I., M. Ehrmann (2004), "Euro area inflation differentials”, ECB Working Paper No. 388.

Arellano, M. and O. Bover (1995), “Another Look at the Instrumental Variable Estimation of Errorcomponents Models", Journal of Econometrics, Vol. 68.

Arellano, M. and S. Bond (1991), "Some Tests of Specification for Panel Data: Monte Carlo Evidence and an Application to Employment Equations", The Review of Economic Studies, Vol. 58.

Backé, P., J. Fidrmuc, T.Reininger and F.Schardax.( 2003), "Price dynamics in Central and Eastern European EU accession countries", Emerging Markets Finance and Trade, 39(3), 42-78.

Barlow, D. (2009), "How did structural reform influence inflation in transition economies?", Economic Systems, forthcoming.

Batini, N., K. Kuttner, D. Laxton (2005), “Does inflation targeting work in emerging markets?” International Monetary Fund. World Economic Outlook. September

Bruno, G.S.F. (2005a), "Estimation and Inference in Dynamic Unbalanced Panel-data Models with a Small Number of Individuals", Stata Journal, Vol. 5, No. 4.

Bruno, G.S.F. (2005b), “Approximating the Bbias of the LSDV Estimator for Dynamic Unbalanced Panel Data Models", Economics Letters, Vol. 87, No. 3.

Bulir, A. and J. Hurník (2008), "Why has inflation in the European Union stopped converging? Journal of Policy Modelling, 30, 341-347.

Bun, M.J.G. and J.F. Kiviet (2003), “On the Diminishing Returns of Higher Order Terms in Asymptotic Expansions of Bias", Economics Letters, Vol. 79.

Bun, M.J.G. and M.A. Carree (2005), "Bias-Corrected Estimation in Dynamic Panel Data Models", Journal of Business and Economic Statistics, Vol. 23. 
Campa, J.M., L. S. Goldberg (2002), "Exchange Rate Pass-Through into Import Prices: A Macro or Micro Phenomenon?" NBER Working Paper No. 8934.

Chmielewski, T., A. Kot (2006), "Impact of globalisation? Changes in the MTM in Poland", National Bank of Poland. Mimeo.

Choueiri, N., F. Ohnsorge, R. van Elkan (2008), "Inflation differential in the EU: A common(factors) approach with implications for EU8 euro adoption prospects”, IMF Working Paper No. 08/21.

Darvas, Z., A.K. Rose and G. Szapáry (2005), "Fiscal divergence and business cycle synchronisation: Irresponsability is idiosyncratic", NBER Working Paper No. 11580.

Dobrinsky, R. (2006), "Catch-up inflation and nominal convergence: The balancing act for new EU entrants", Economic Systems, 30(4), 424-442.

Égert, B., L. Halpern and R. MacDonald (2006), “Equilibrium Exchange Rates in Transition Economies: Taking Stock of the Issues", Journal of Economic Surveys.

European Central Bank (2003), "Direct impact of changes in administered prices and indirect taxes on euro area HICP developments”, ECB Monthly Report March. 35-36.

European Commission (2006), "Inflation report", May.

Frankel, J.A., A.K. Rose (1998), "The endogeneity of the optimum currency area criteria", Economic Journal. 108(449). 1009-25.

Hammermann, F. (2007), "Nonmonetary determinants of inflation in Romania: A decomposition”, Kiel Working Paper No. 1322.

Hammermann, F. and M. Flanagan (2009), "What explains inflation differentials across transition economies?’Economics of Transition, 17(2), 297-328.

Hansen, B. (1999), “Threshold Effects in Non-dynamic Panels: Estimation, Testing and Inference”, Journal of Econometrics, Vol. 93.

Hofmann, B. and H. Remsperger. 2005. Inflation differentials among the euro area countries: potential causes and consequences. Journal of Asian Economics. 6(3). 403-419.

Honohan, P. and P. Lane. 2004. Exchange rates and inflation under EMU: an update. CEPR Discussion Paper No. 4583.

Honohan, P., P. Lane (2004), "Exchange rates and inflation under EMU: an update”, CEPR Discussion Paper No. 4583. 
Kiviet, J.F. (1995), “On Bias, Inconsistency and Efficiency of Various Estimators in Dynamic Panel Data Models", Journal of Econometrics, Vol. 68.

Kocenda, E., A. Kutan and T. Yigit (2006), "Pilgrims to the Eurozone: How far, how fast?". Economic Systems. 30(4). 311-327.

Lim, G.C (2009), “Inflation targeting”, Australian Economic Papers, 42(1), 110-118.

Lommatzsch, K. and S. Tober (2004), "What is behind the real appreciation of the accession countries'currencies? An investigation of the PPI-based real exchange rate", Economic Systems. 28(4), $383-403$.

Lünnemann, P. and T.Y. Mathä (2005), "Regulated and services prices and inflation persistence", ECB Working Paper No. 466.

MacDonald, R. and C. Wójcik (2008), "Catching-up inflation differentials in a heterogeneous monetary union: some implications for the euro area and new EU member states", Economic Systems, 32(1), 4-16.

Mihaljek, D. and M. Klau (2008), "Catching-up and inflation in transition economies: the BalassaSamuelson effect revisited", BIS working paper no. 270.

Mody, A. and F. Ohnsorge (2007), “Can domestic policies influence inflation?” IMF Working Paper No $07 / 257$.

Rogers, J.H.(2001), "Price level convergence, relative prices and inflation in Europe", Board of Governors of the Federal Reserve System. International Finance Discussion Papers No. 699.

Rogers, J.H. (2002), " Monetary union, price level convergence and inflation: how close is Europe to the United States?", Board of Governors of the Federal Reserve System. International Finance Discussion

Sala-i-Martin, X., G. Dopperhofer and R.I. Miller (2004),"Determinants of long-run growth: a Bayesian averaging of classical estimates (BACE) approach", American Economic Review, 94(4), 813-835.

Taylor, J. (2000), "Low Inflation. Pass-Through and the Pricing Power of Firms", European Economic Review 44(7). 1389-1408.

Vasicek, B. (2009), "Inflation dynamics and the new Keynesian Phillips curve in the EU-4", William Davidson Institute Working Paper no. 971.

Zoli, E. (2009), "Commodity price volatility, cyclical fluctuations and convergence: What is ahead for inflation in emerging Europe?" IMF Working Paper No. 09/41. 
ANNEX

Table A1. The implied size of the Balassa-Samuelson effect - simple accounting framework 1997-2007

\begin{tabular}{|c|c|c|c|c|c|c|c|c|c|c|c|c|}
\hline & \multicolumn{4}{|c|}{ Productivity growth } & \multicolumn{8}{|c|}{ Implied Balassa-Samuelson effect } \\
\hline & \multicolumn{2}{|c|}{$\begin{array}{l}\text { Industry } \\
\text { based on }\end{array}$} & \multicolumn{2}{|c|}{$\begin{array}{l}\text { Manufacturing } \\
\text { based on }\end{array}$} & \multicolumn{2}{|l|}{ A } & \multicolumn{2}{|c|}{ B } & \multicolumn{2}{|c|}{ C } & \multicolumn{2}{|l|}{ D } \\
\hline & $\begin{array}{c}\text { Hours } \\
\text { worked }\end{array}$ & $\begin{array}{l}\text { Number } \\
\text { of workers }\end{array}$ & $\begin{array}{c}\text { Hours } \\
\text { worked }\end{array}$ & $\begin{array}{l}\text { Number } \\
\text { of workers }\end{array}$ & narrow & wide & narrow & wide & narrow & wide & narrow & wide \\
\hline & $\mathbf{A}$ & $\mathbf{B}$ & $\mathbf{C}$ & D & & & & & & & & \\
\hline \multicolumn{13}{|c|}{ Old EU member states } \\
\hline BEL & -- & 3.1 & -- & 3.1 & & & 0.4 & 0.8 & -- & -- & 0.4 & 0.8 \\
\hline DNK & 2.3 & 2.7 & 3.8 & 4.4 & 0.3 & 0.6 & 0.3 & 0.6 & 0.6 & 1.3 & 0.6 & 1.3 \\
\hline DEU & 3.8 & 3.5 & 3.7 & 3.5 & 0.5 & 1.1 & 0.6 & 1.3 & 0.5 & 1.0 & 0.6 & 1.2 \\
\hline IRL & 7.7 & 7.9 & -- & -- & 1.4 & 2.6 & 1.8 & 3.0 & -- & -- & -- & -- \\
\hline GRC & 3.7 & 3.4 & 4.3 & -- & 0.4 & 0.9 & 0.3 & 0.6 & 0.5 & 1.0 & -- & -- \\
\hline ESP & 1.6 & 1.2 & 1.8 & -- & 0.5 & 0.7 & 0.5 & 0.6 & 0.3 & 0.5 & -- & -- \\
\hline FRA & 4.1 & 3.2 & 4.2 & -- & 0.7 & 1.1 & 0.6 & 1.0 & 0.7 & 1.1 & -- & -- \\
\hline ITA & 0.6 & 0.4 & 0.6 & 0.3 & 0.1 & 0.2 & 0.2 & 0.2 & 0.1 & 0.1 & 0.2 & 0.1 \\
\hline LUX & -- & 2.8 & -- & 2.7 & & & 0.3 & 0.5 & -- & -- & 0.3 & 0.5 \\
\hline NLD & 2.9 & 2.5 & 3.2 & 3.0 & 0.1 & 0.5 & 0.2 & 0.6 & 0.2 & 0.8 & 0.3 & 0.8 \\
\hline AUT & 4.1 & & 4.1 & -- & 0.9 & 1.5 & & & 1.0 & 1.5 & & \\
\hline PRT & -- & 2.8 & -- & 2.3 & -- & -- & 0.6 & 0.8 & -- & -- & 0.6 & 0.7 \\
\hline FIN & 6.5 & 6.4 & 6.8 & 6.8 & 1.2 & 2.1 & 1.3 & 2.2 & 1.3 & 2.3 & 1.4 & 2.4 \\
\hline SWE & 5.7 & 6.0 & 6.4 & 7.5 & 0.6 & 1.6 & 0.8 & 1.8 & -- & -- & 1.1 & 2.5 \\
\hline GBR & -- & 3.21 & -- & -- & -- & -- & 0.4 & 0.7 & -- & -- & -- & -- \\
\hline \multicolumn{13}{|c|}{ New EU member states } \\
\hline BGR & 3.4 & 3.4 & 5.9 & 6.2 & 0.1 & 0.2 & 0.2 & 0.2 & 0.2 & 0.4 & 0.4 & 0.7 \\
\hline CZE & 5.7 & 5.6 & 6.8 & 6.7 & 0.5 & 1.1 & 0.5 & 1.2 & 0.6 & 1.5 & 0.6 & 1.6 \\
\hline EST & 9.3 & 9.9 & 9.5 & 11.5 & 0.3 & 0.9 & 0.4 & 0.9 & 0.3 & 0.9 & 0.6 & 1.2 \\
\hline LVA & & 6.0 & & 6.9 & -- & & 0.1 & 0.1 & -- & -- & 0.2 & 0.3 \\
\hline LTU & 7.9 & 8.9 & 8.8 & 10.1 & 0.4 & 0.7 & 0.5 & 0.7 & 0.5 & 0.7 & 0.7 & 0.9 \\
\hline HUN & 6.3 & 6.1 & 6.8 & -- & 0.5 & 1.2 & 0.5 & 1.2 & 0.3 & 1.1 & -- & -- \\
\hline POL & 6.9 & 7.8 & 9.6 & 9.2 & 0.5 & 0.9 & 0.6 & 1.0 & 0.9 & 1.7 & 0.7 & 1.5 \\
\hline ROM & & 4.97 & -- & -- & -- & -- & 0.1 & 0.4 & --- & -- & -- & -- \\
\hline SVN & & 6.5 & -- & 6.6 & -- & -- & 0.6 & 1.4 & -- & ---- & 0.6 & 1.4 \\
\hline SVK & 8.9 & 8.8 & 9.7 & 9.5 & 1.2 & 1.6 & 1.2 & 1.7 & 1.2 & 1.9 & 1.3 & 2.0 \\
\hline
\end{tabular}

Source: author's calculations based on data drawn from Eurostat's NewCronos.

Notes: narrow and wide refer to market services and all services, respectively. The implied Balassa-Samuelson effect is computed as the average rate of growth in the open sector (either manufacturing or industry) minus the rate of growth in market or all services. The difference of productivity growth is multiplied by the share of marker or all services in the HICP. 


\section{DAVIDSON INSTITUTE WORKING PAPER SERIES - Most Recent Papers}

The entire Working Paper Series may be downloaded free of charge at: www.wdi.umich.edu

CURRENT AS OF $6 / 14 / 10$

\begin{tabular}{|c|c|c|}
\hline Publication & Authors & Date \\
\hline $\begin{array}{l}\text { No. 991: Catching-up and inflation in Europe: Balassa- } \\
\text { Samuelson, Engel's Law and other Culprits }\end{array}$ & Balázs Égert & June 2010 \\
\hline $\begin{array}{l}\text { No. 990: UNLOCKING PRODUCTIVE ENTREPRENEURSHIP IN AFRICA'S LEAST } \\
\text { DEVELOPED COUNTRIES }\end{array}$ & Zuzana Brixiova & June 2010 \\
\hline $\begin{array}{l}\text { No. 989: The VARying Effect of Foreign Shocks in Central \& Eastern } \\
\text { Europe }\end{array}$ & $\begin{array}{l}\text { Rebeca Jimenez-Rodriguez, } \\
\text { Amalia Morales-Zumaquero } \\
\text { \& Balazs Egert }\end{array}$ & May 2010 \\
\hline $\begin{array}{l}\text { No. 988: Implications of Bank Ownership for the Credit Channel of } \\
\text { Monetary Policy Transmission: Evidence from India }\end{array}$ & $\begin{array}{l}\text { Sumon K. Bhaumik, Vinh Dang } \\
\text { and Ali M. Kutan }\end{array}$ & May 2010 \\
\hline $\begin{array}{l}\text { No. 987: Mother or motherland: Can a government have an impact on } \\
\text { educational attainment of the population? Preliminary evidence from } \\
\text { India }\end{array}$ & $\begin{array}{l}\text { Sumon Kumar Bhaumik and } \\
\text { Manisha Chakrabarty }\end{array}$ & May 2010 \\
\hline $\begin{array}{l}\text { No. 986: Does FDI spur innovation, productivity and knowledge sourcing } \\
\text { by incumbent firms? Evidence from manufacturing industry in Estonia }\end{array}$ & Priit Vahter & April 2010 \\
\hline No. 985: Exports and Property Prices in France: Are They Connected? & $\begin{array}{c}\text { Balazs Egert and } \\
\text { Rafal Kierzenkowski }\end{array}$ & May 2010 \\
\hline $\begin{array}{l}\text { No. 984: Methodologies of Analyzing Inter-Regional Income Inequality } \\
\text { and Their Applications to Russia }\end{array}$ & Konstantin Gluschenko & April 2010 \\
\hline $\begin{array}{l}\text { No. 983: Foreign News and Spillovers in Emerging European Stock } \\
\text { Markets }\end{array}$ & Evzen Kocenda and Jan Hanousek & $\begin{array}{l}\text { May } \\
2010\end{array}$ \\
\hline $\begin{array}{l}\text { No. 982: The Economic and Monetary Union's effect on (international) } \\
\text { trade: the case of Slovenia before euro adoption }\end{array}$ & $\begin{array}{l}\text { Aleksander Aristovnik and } \\
\text { Matevz Meze }\end{array}$ & $\begin{array}{l}\text { April } \\
2010\end{array}$ \\
\hline $\begin{array}{l}\text { No. 981: In Time of Troubles: Challenges and Prospects in the Middle } \\
\text { East and North Africa }\end{array}$ & Imed Drine & $\begin{array}{l}\text { April } \\
2010\end{array}$ \\
\hline No. 980: A Composite Leading Indicator of Tunisian Inflation & Mohamed Daly Sfia & $\begin{array}{c}\text { March } \\
2010\end{array}$ \\
\hline $\begin{array}{l}\text { No. 979: Financial stability, monetary autonomy and fiscal interference: } \\
\text { Bulgaria in search of its way, 1879-1913 }\end{array}$ & $\begin{array}{l}\text { Kalina Dimitrova and } \\
\text { Luca Fantacci }\end{array}$ & Feb 2010 \\
\hline $\begin{array}{l}\text { No. 978: The Supply Side of Innovation: H-1B Visa Reforms and US } \\
\text { Ethnic Invention }\end{array}$ & $\begin{array}{l}\text { William R. Kerr and } \\
\text { William F. Lincoln }\end{array}$ & Feb 2010 \\
\hline $\begin{array}{l}\text { No. 977: Data Collection Procedures Equivalence in International } \\
\text { Business Research }\end{array}$ & $\begin{array}{l}\text { Agnieszka Chidlow, } \\
\text { Anna Morgan-Thomas } \\
\text { and Pervez N. Ghauri }\end{array}$ & Feb 2010 \\
\hline $\begin{array}{l}\text { No. 976: Direct and Indirect Effects of FDI in Emerging European } \\
\text { Markets: A Survey and Meta-analysis }\end{array}$ & $\begin{array}{l}\text { Jan Hanousek, Evzen Kocenda } \\
\text { and Mathilde Maurel }\end{array}$ & $\begin{array}{c}\text { March } \\
2010\end{array}$ \\
\hline $\begin{array}{l}\text { No. 975: MODELING INSTITUTIONS, START-UPS AND PRODUCTIVITY DURING } \\
\text { TRANSITION }\end{array}$ & $\begin{array}{c}\text { Zuzana Brixiová and } \\
\text { Balázs Égert } \\
\end{array}$ & Feb 2010 \\
\hline $\begin{array}{l}\text { No. 974: Pegging the future West African single currency in regard to } \\
\text { internal/external competitiveness: a counterfactual analysis }\end{array}$ & $\begin{array}{l}\text { Gilles Dufrénot and } \\
\text { Kimiko Sugimoto } \\
\end{array}$ & Dec 2009 \\
\hline $\begin{array}{l}\text { No. 973: Unemployment and finance: how do financial and labour market } \\
\text { factors interact? }\end{array}$ & $\begin{array}{l}\text { Donatella Gatti, Christophe Rault } \\
\text { \& Anne-Gaël Vaubourg }\end{array}$ & $\begin{array}{c}\text { January } \\
2010\end{array}$ \\
\hline No. 972: Identifying Social Entrepreneurs Serving the Poor at the BoP & Abraham M. George & $\begin{array}{l}\text { December } \\
2009\end{array}$ \\
\hline $\begin{array}{l}\text { No. 971: Inflation dynamics and the New Keynesian Phillips curve in the } \\
\text { EU-4 }\end{array}$ & Bořek Vašíček & $\begin{array}{l}\text { October } \\
2009\end{array}$ \\
\hline $\begin{array}{l}\text { No. 970: International Financial Integration And Real Exchange Rate } \\
\text { Long-Run Dynamics In Emerging Countries: Some Panel Evidence }\end{array}$ & $\begin{array}{l}\text { Guglielmo Maria CAPORALE, } \\
\text { Thouraya HADJ AMOR } \\
\text { and Christophe RAULT }\end{array}$ & Sept 2009 \\
\hline
\end{tabular}

